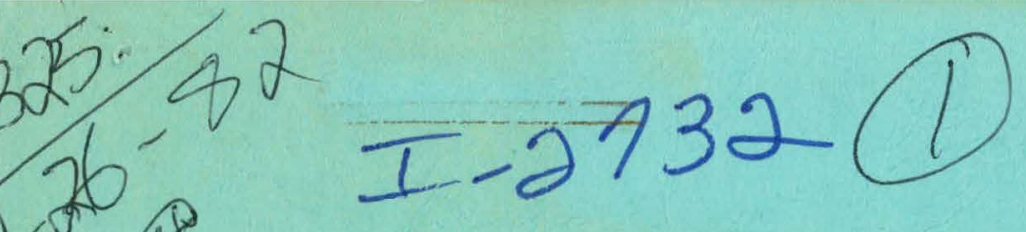

\title{
STABILITY OF CERAMIC
}

WASTE FORMS IN POTENTIAL

REPOSITORY ENVIRONMENTS:

A REVIEW

DOE Research and Development Report

\section{DO NOT MICROFILM - COVER}

Prepared for the United States

Department of Energy,

Savannah River Operations Office

under Contract Number DE-ACO9-79ET41900 


\section{DISCLAIMER}

This report was prepared as an account of work sponsored by an agency of the United States Government. Neither the United States Government nor any agency Thereof, nor any of their employees, makes any warranty, express or implied, or assumes any legal liability or responsibility for the accuracy, completeness, or usefulness of any information, apparatus, product, or process disclosed, or represents that its use would not infringe privately owned rights. Reference herein to any specific commercial product, process, or service by trade name, trademark, manufacturer, or otherwise does not necessarily constitute or imply its endorsement, recommendation, or favoring by the United States Government or any agency thereof. The views and opinions of authors expressed herein do not necessarily state or reflect those of the United States Government or any agency thereof. 


\section{DISCLAIMER}

Portions of this document may be illegible in electronic image products. Images are produced from the best available original document. 


\section{NOTICE}

This report was prepared as an account of work sponsored by the United States Government. Neither the United States nor the United States Department of Energy, nor any of their employees, nor any of their contractors, subcontractors, or their employees, makes any warranty, express or implied, or assumes any legal liability or responsibility for the accuracy, completeness or usefulness of any information, apparatus, product or process disclosed, or represents that its use would not infringe privately owned rights.

Printed in the United States of America

Available trom

National Technical Information Center

U.S. Department of Commerce

5285 Port Royal Road

Springfield, Virginia 22161

NTS price codes

Printed copy: $\$ 6.00$

Microfiche copy: A01 
$\mathrm{DOE} / \mathrm{ET} / 41900--13$

DE82 013288

DOE/ET/41900-13

(ESG-DOE-13364)

NUCLEAR WASTE

MANAGEMENT

UC-70

STABILITY OF CERAMIC

WASTE FORMS IN POTENTIAL

REPOSITORY ENVIRONMENTS:

A REVIEW

By

R. J. JOHNSTON

R. A. PALMER

Materials Evaluation Unit

Materials Science Group

Rockwell Hanford Operations

Richland, Washington

Energy Systems Group 8900 De Soto Avenue

Canoga Park, California 91304

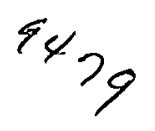




\section{DISTRIBUTION}

This report has been distributed according to the category "Nuclear Waste Management," as given in the Standard Distribution for Unclassified Scientific and Technical Reports, DOE/TIC-4500. 


\section{ABSTRACT}

Most scenarios for geologic disposal of high-level nuclear waste include the eventual intrusion of groundwater into the repository. Reactions in the system and eventual release of the radionuclides, if any, will be controlled by the chemistry of the groundwater, the surrounding rock, the waste form, and any engineered barrier materials that are present, as well as by the temperature and pressure of the system. This report is a compilation and evaluation of the work completed to date on interactions within the waste-form/host-rock/groundwater system at various points in its lifetime. General results from leaching experiments are presented as a basis for comparison. The factors involved in studying the complete system are discussed so that future research may avoid some of the oversights of past research. Although relatively little hard data on prototype waste-form/repository-system interactions exist at this time, the available data and their implications are discussed. Sorption studies and models for predicting radionuclide migration are also presented, again with a study of the factors involved.

We hope that placing all of these results in one consolidated report will provide a more lucid picture of waste-form durability. We also hope that other investigators will be encouraged to design and perform new waste-form/host-rock compatibility experiments so that a more complete data base may be produced. 
THIS PAGE , WAS INTENTIONALLY

\section{LEFT BLANK ;}

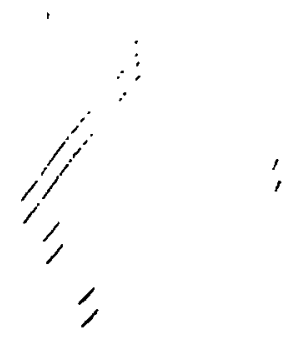


I. Introduction. $\ldots \ldots \ldots \ldots \ldots \ldots \ldots \ldots \ldots \ldots \ldots \ldots \ldots \ldots \ldots \ldots \ldots \ldots$

II. General Durability............................. 5

III. Waste-Form/Host-Rock/Groundwater Interactions .............. 15

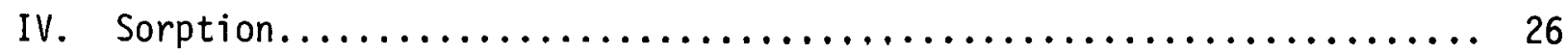

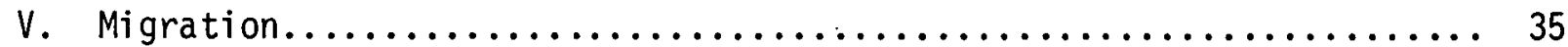

VI. Summary and Conclusions........................... 39

Bibliography................................... 41

\section{TABLES}

1. Typical Leachabilities of Several Ceramic Waste Forms at Elevated Temperatures....................................... 7

2. Residual Solution Analyses from Hydrothermal Leaching of Synthetic Waste Glass.............................. 11

3. Hydrothermal Leaching Data for Supercalcine Ceramic and SYNROC Ceramic.

4. Residual Solution Compositions from Hydrothermal Reactions of Pacific Northwest Laboratory 76-68 Glass with Basalt and

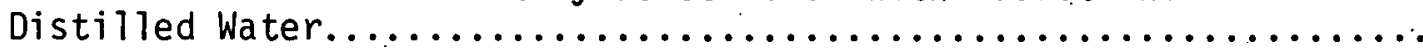

5. Residual Solution Compositions from Hydrothermal Reactions

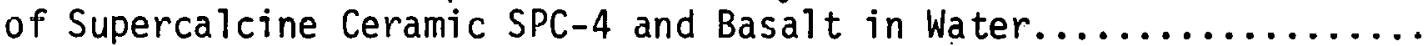

6. Sorption of Selected Radionuclides by Umtanum Basalt and Basalt Secondary Minerals from Synthetic Grande Ronde Groundwater......... 27

7. Sorptive and Desorptive Behavior of Selected Isotopes on Climax Stock Granite.................................... 29

8. Sorptive Behavior of Minerals in the Delaware Basin and Adjacent to the Hainesville Salt Dome........................ 31

9. Sorption of Selected Radionuclides by Argillite from the Eleana Formation, Nevada Test Site........................ 32

10. Sorption Ratios for Various Nevada Test Site Tuffs.............. 34

11. Factors Involved in Radionuclide Migration Estimates........... 36 


\section{FIGURES}

Page

1. Modified IAEA Leach Test on Simulated. Waste Glass (76-68),

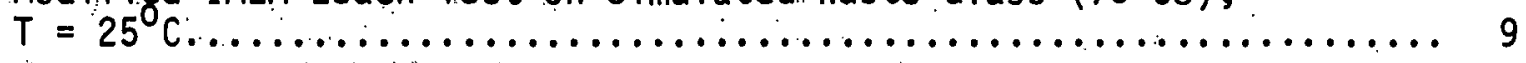

2. Effect of Temperature on 76-68 Waste Glass Leach Rates........... 10 


\section{INTRODUCTION}

The function of a nuclear waste form is to retain radionuclides until they have decayed to stable isotopes. How well a given waste form is able to perform this task without additional help (i.e., engineered barriers) is a function of its ability to resist reactions with the repository environment that release radioisotopes into the groundwater. Each geology imposes a different set of geochemical, hydrochemical, and physical conditions that must be considered. Significant variations in temperature, pressure (both functions of depth), and chemistry are possible at different sites with the same rock type and even at the same site if the repository locations are at significantly different depths.

These factors, coupled with the heat load generated by the waste form, govern the conditions that a nuclear waste form should ideally be able to withstand.

Most scenarios for geologic disposal of high-level nuclear waste include the eventual intrusion of groundwater into the repository. Should this occur when the waste form is relatively young and emitting substantial quantities of heat, a hydrothermal reaction system is established. If the intrusion does not occur until the radionuclides in the waste form have largely decayed to stable isotopes, a different reaction system exists, in which the temperature is largely governed by the local geothermal gradient and the repository's depth. When these factors are added to the various geologies under consideration and their chemical differences, a relatively large matrix of potential environments which a ceramic nuclear waste form must survive is established.

Experimenters studying such reactions have broken them down into simpler systems, reducing the number of variables to establish better control and to achieve better understanding of the mechanisms involved in waste-form degradation. The simplest of these experiments, and that most widely performed to date, has been the standard leach test, in which the waste form is reacted with either deionized water or a simulated groundwater. The bulk of such tests have occurred at $0.1 \mathrm{MPa}$ (one atmosphere) and 20 to $99^{\circ} \mathrm{C}$, although a smaller number of experiments have been conducted to pressures of up to $40 \mathrm{MPa}$ and temperatures of $300^{\circ} \mathrm{C}$ 
in various hydrothermal devices. The former conditions are somewhat representative of those that will exist for an old emplaced waste, although the pressures are much lower than those probable in the repository, because either hydrostatic or lithostatic pressure will probably have been reestablished by the time the waste has cooled (Smith et al., 1980). The latter conditions duplicate some of those that a young waste form might experience in a flooded, collapsed repository. Such tests are useful measures of relative waste-form stability under a variety of conditions but are insufficient to predict the reactions, if any, that could occur between the waste form and the repository environment.

In reality, the repository system will be much more complicated, containing reactants other than just the waste form and the groundwater. The chemical and mineral compositions of the host rock and their variations will also play an important role. Heat-induced reactions between the groundwater and the host rock will alter solution chemistries, probably before the groundwater encounters the waste form. Such reactions may promote reactions between the repository system and the waste form that are not predictable by simple leach tests like those described above. Dissolution of the waste-form canister, which in current systems is a metal, will also alter solution chemistries and affect reactions in the system. To date, a limited number of tests have been performed on various waste forms in contact with groundwater and candidate repository rocks. A very few experiments have included potential canister materials.

Waste-form weaknesses uncovered by such experiments may require that additional protection be provided for the waste form. Engineered barriers, materials specifically designed to protect the waste form and/or prevent release of leached radionuclides from the repository, would be devised to provide the necessary protection. Such materials may include sorbent or swelling clays, overpacks (for such purposes as pH buffering), and tunnel backfills, which may include materiais other than just crushed repository rock (Smith et a1., 1980). Although the manmade barriers should counteract detrimental reactions in the repository/wasteform system, tests of the entire assemblage will be required to uncover unexpected and potentially adverse interactions among the natural materia:, the waste form, and the manmade barriers. Such tests are only in the planning stage at the present time, as engineered barrier development is in its early phases. 
Once groundwater has reacted with the waste form and begins to leave the vicinity of the emplaced waste, the rate at which radionuclides migrate within the system toward the biosphere wịll be governed in part by interactions between the leachate and the geology. Numerous experiments to measure sorption reactions between various rocks and radionuclide-bearing solutions have been performed. These experiments have been the basis of estimates of radionuclide migration rates over long time periods from various conceptual repositories.

In this document, the stabilities of various ceramic waste forms in environments under consideration for repository emplacement will be discussed. Available data on the interactions of ceramic waste forms with the five geologies discussed in a previous report (Johnston and Palmer, 1981) will be summarized and discussed. As noted above, studies of interactions between waste forms, repository host rocks, and groundwaters are relatively limited, nearly nonexister.t for. more complex systems such as those that include canister material. Consequently, this report. will be limited to discussions of waste-form/water interactions and waste-form/water/rock interactions that have been studied to date. Experiments required to determine the stability of waste forms in more complicated systems will also be discussed briefly.

The waste forms to be considered include borosilicate glass (which in the strictest sense may be considered a ceramic), which has been the subject of the greatest number of waste-form development and stability experiments of all the various waste forms. These measurements provide a convenient baseline against which the performance of various crystalline ceramic forms may be evaluated. Other waste forms to be discussed in some detail are supercalcine ceramic (MCCarthy, 1977), SYNROC (Ringwood, 1978), coated ceramic [a supercalcine ceramic with very tough coatings (Rusin et al., 1979)], and Tailored Ceramic (Harker et a1., 1980a). A few other types of ceramic waste forms, such as glass-ceramics and cermets (ceramic in a metal matrix) have been the subject of limited development work. As stability data for these waste forms are generally limited, they will not be discussed in this report. Some long-term leaching data are available for the Sandia titanate ceramic (Kenna et al., 1979) and will be briefly discussed 
in the next section. Data from the reactions of simulated spent fuel and individual phases within spent fuel with repository rocks and groundwater will also be discussed. These data are relevant to other waste-form development programs. 


\section{GENERAL DURABILITY}

Before discussing the more complex topic of ceramic waste-form/host-rock/ groundwater interactions, we must establish a baseline data set for the general durability of waste forms in aqueous environments under a variety of conditions. Many different tests have been devised by organizations such as the Internal Standards Organization (ISO), International Atomic Energy Agency (IAEA), American Nuclear Society (ANS), and Materials Characterization Center (MCC). Both static and dynamic tests have been employed in the study of waste-form durability. The resistance of prototype waste forms to attack by deionized water, acid and alkaline solutions, and various simulated groundwaters, including brine and siticate solutions, has been studied by such methods. Other test parameters have been varied, including temperature and pressure, with hydrothermal testing used to determine leach resistance at temperatures in the range of 100 to $400^{\circ} \mathrm{C}$ and pressures up to $40 \mathrm{MPa}$. These tests have allowed researchers to study the rates at which selected radionuclides are extracted from the waste forms under a variety of conditions.

Although much data have been collected on the leachabilities of selected radionuclides from various waste forms (in general, those that are thought to present the greatest hazard to mankind), comparatively little work has been performed to firmly establish the underlying mechanisms as a function of experimental conditions. Much of the data suggest that, during the initial phases, the rate controlling mechanism for waste-form leaching is internal bulk diffusion (e.g., Brawer et al., 1975). However, these and other researchers have noted that variations in conditions such as $\mathrm{pH}$ could change the mechanism to dissolution of the matrix itself or to a complex mixture of processes.

Leaching can proceed by the simultaneous action of several mechanisms, such as diffusion, erosion, dissolution, and grain boundary attack in crystalline solids. The relative importance of these mechanisms may change as a function of temperature, pressure, solution flow rate (saturation effects), and radionuclide of interest (ionic size, bond type, quantity present in matrix, quantity 
of other similar elements present, etc.), to name a few. For example, sodium may leach more rapidly than cesium simply because it is a smaller ion, able to diffuse more readily through the matrix. As the repository and waste form age, many of the environmental factors discussed above will vary, possibly altering the mechanism(s) controlling leaching and, consequently, the leach rates." Kaplan (1980) has noted that even if only one mechanism is operational in the corrosion of a material. (in the case of his work, ancient glasses), it may manifest itself in many different ways. Sufficient long-duration leaching data are not available to permit a determination of long-term mechanisms (or variations thereof) controlling leaching of a waste form exposed to a single set of environmental conditions, let alone the large number of possible variations caused by altering the matrix of environmental factors. It seems unlikely that a single mechanism will control radionuclide leaching from a given waste form during its lifetime.

In this section, the large amount of data on the leachability of ceramics designed to encapsulate nuclear waste is briefly summarized. Such baseline data can allow determination of whether the synergistic effects of the host rock in reactions involving the entire repository system are detrimental or beneficial.

One of the most commoniy employed leach test methods currentiy in use is the Soxhlet test, as described by Mendel et a1. (1977). This test and others, which operate at temperatures of $100^{\circ} \mathrm{C}$ or less and atmospheric pressure, have accounted for the vast majority of the waste-form durability tests performed to date. Hydrothermal tests, in which the resistance of the waste form to superheated solutions such as may be encountered in the early life of the repository is measured, have been a recent innovation (McCarthy et al., 1978). Results from a variety of these tests are presented in a generalized form in Table 1. These data have been obtained from a variety of tests performed under many sets of experimental conditions (note footnotes) and in many cases are based on the leaching of different radionuclides. "The values are presented in this fashion to show the range of reaching results that have been obtained with various classes of tests for the 1 isted waste forms and are comparable one to another in that sense alone. As is evident from the data presented, the disparities among the various methods

DOE/ET/41900-13

(ESG-DOE-13364) 
TABLE 1

TYPICAL LEACHABILITIES OF SEVERAL CERAMIC WASTE FORMS AT. ELEVATED TEMPERATURES

$\left(\mathrm{g} / \mathrm{cm}^{2} \cdot \mathrm{d}\right)$

\begin{tabular}{|c|c|c|c|}
\hline Waste Form & Soxhlet ${ }^{a}$ & Hydrothermal & Other \\
\hline Glass & $10^{-4}-10^{-6}$ & $10^{-3}-10^{-4^{b}}$ & $9 \times 10^{-6^{c}}$ \\
\hline $\begin{array}{l}\text { Supercalcine } \\
\text { Ceramic. }\end{array}$ & $10^{-5}-10^{-6}$ & $10^{-4^{d}}$ & $8 \times 10^{-6^{c}}$ \\
\hline SYNROC & $10^{-4}-10^{-5}$ & $10^{-3}-10^{-6^{\mathrm{e}}}$ & $10^{-1}-10^{-3}$ \\
\hline $\begin{array}{l}\text { Sintered Tita- } \\
\text { nate Ceramic }\end{array}$ & $10^{-4}-10^{-5}$ & $N R^{g}$ & ṆR \\
\hline Coated Ceramic & NR & NR & $10^{-7}-10^{-9^{h}}$ \\
\hline
\end{tabular}

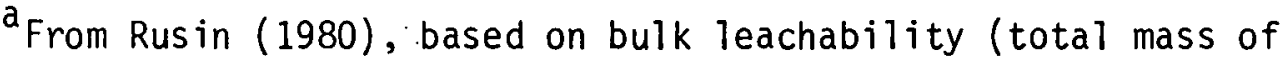
al1 elements lost from waste form during test).

${ }^{b}$ From Rockwell Hanford Operations (1980), based on Cs release, $150^{\circ} \mathrm{C}, 10 \mathrm{MPa}, 14$ days, dist17led water; and Westsik and Turcotte $(1979), 250^{\circ} \mathrm{C}, 6.9 \mathrm{MPa}, 3$ days, $\mathrm{NaCl}$ brine.

$\mathrm{C}_{\text {From Rusin }}(1980), 99^{\circ} \mathrm{C}$, distilled water.

$\mathrm{d}_{\text {From Rusin }}(1980) ; 250^{\circ} \mathrm{C}$, salt brine.

eAfter Westsik et a]. (1980), 3 days, distilled water, $100-300^{\circ} \mathrm{C}$, 13.8 $\mathrm{MPa}$, based on Cs and La for lower and upper limits, respectively. Bulk leachability lies between these values.

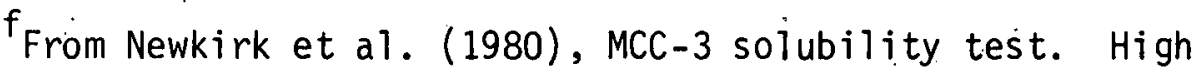
leach rate due mainly to Cs loss from hollandite in samples tested.

${ }^{g_{N R}}=$ not reported .

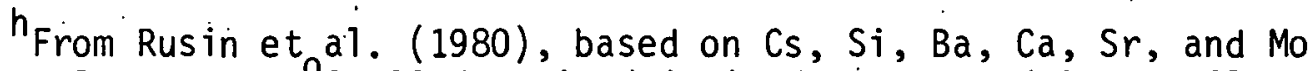
release at $90^{\circ} \mathrm{C}, 28$ days in deionized water, and $0.5 \mathrm{M} \mathrm{NaCl}$ brine from coated supercalcine ceramic pellets. 
(technique, experimental conditions, sample preparation) make accurate comparisons difficult and sometimes produce conflicting results. Further perturbations are introduced when the "standard" tests are modified by researchers, for whatever reason. Rigorously standardized leach tests, such as those proposed by the MCC, are still under dévelopment.

Durability tests have been useful in establishing trends for the variations in waste-form reactivity as a function of several repository parameters, including reaction time, solution composition, temperature, and pressure. Typical effects of variations in reaction time and solution composition are illustrated in Figure 1 (Bradley, 1980). In this case, a modified IAEA leach test was used on a simulated waste glass, Pacific Northwest Laboratory Formulation 76-68 (McElroy, 1979). The data indicate that the leach rate gradually decreased as a function of time, approaching an apparent steady-state value after $\sim 22$ days' reaction. Similar time-dependent behavior is observed for the leaching of other elements, probably due to the buildup of the ion in solution (saturation) or depletion of the more easily removed material near the sample surface. The differences resulting from variation of the solution composition are readily apparent. Dissolved ions in the solution can promote or inhibit the removal of selected elements (or matrix dissolution) by such mechanisms as soluble complex formation or alteration of the solubility of specific elements.

Similar leaching behavior has been reported by Kenna et al. (1979) for longterm Soxhlet testing of two waste glass formulations and a titanate crystalline ceramic. In these experiments, testing was performed continuously over several months, with periodic replacement of the leach solution (distilled water). All materials tested exhibited a cyclic behavior for absolute leach rate, with the titanate ceramic exhibiting the lowest leach rate and the least amplitude in the cycle. Such results illustrate the effects of cyclic conditions on prototype waste forms. The "sawtooth". effect, shown in Figure $I$ and observed by Kenna et al. (1979), has also been observed in the results of Soxhlet leaching tests on supercalcine ceramic, along with a buildup of weathered powder on the bottom of the vessel (Ross et a1., 1979; Scheetz et al., 1979). A possible explanation advanced 


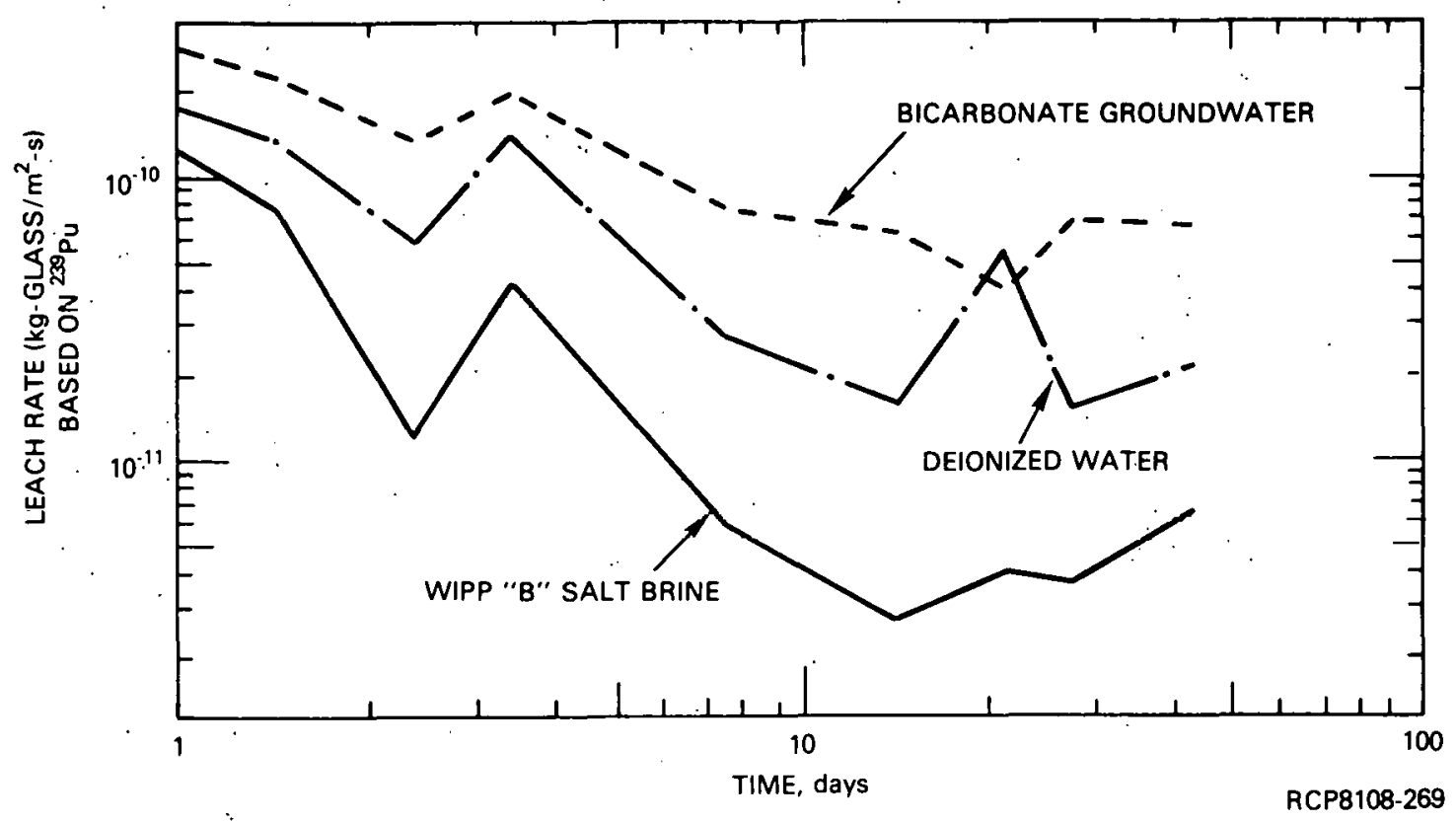

Figure 1. Modified IAEA Leach Test on Simulated Waste Glass (76-68), T $=25^{\circ} \mathrm{C}$ (Bradley, 1980). Bicarbonate "groundwater" $=2.52 \mathrm{~g} / 1 \mathrm{NaHCO}_{3}$ in deionized water (Bradley et al., 1979). For WIPP "B" brine composition, see Johnston and PaImer (1981).

for the effect in some cases (Smith et al., 1980) is a hydration-spallation process, in which a layer of material on the waste form gradually hydrates (or is otherwise altered) and spalls away, exposing fresh surfaces that are more susceptible to leaching. Precipitation of phases containing the dissolved material has been advanced as an explanation for the observed decreases in dissolved solids in the leaching solutions.

Some effects of temperature and solution chemistry on overall leach rates for 76-68.glass are shown in Figure 2. As one might expect, leach rates increase with increasing temperature. Leach-rate increases as a function of temperature have also been reported for ceramics such as supercalcine ceramic and SYNROC (Westsik et al., 1980). Only the magnitudes vary when overall leaching is considered, with crystalline ceramics usually exhibiting somewhat lower leach rates for individual elements as compared to glassy materials, particularly at elevated temperatures. 


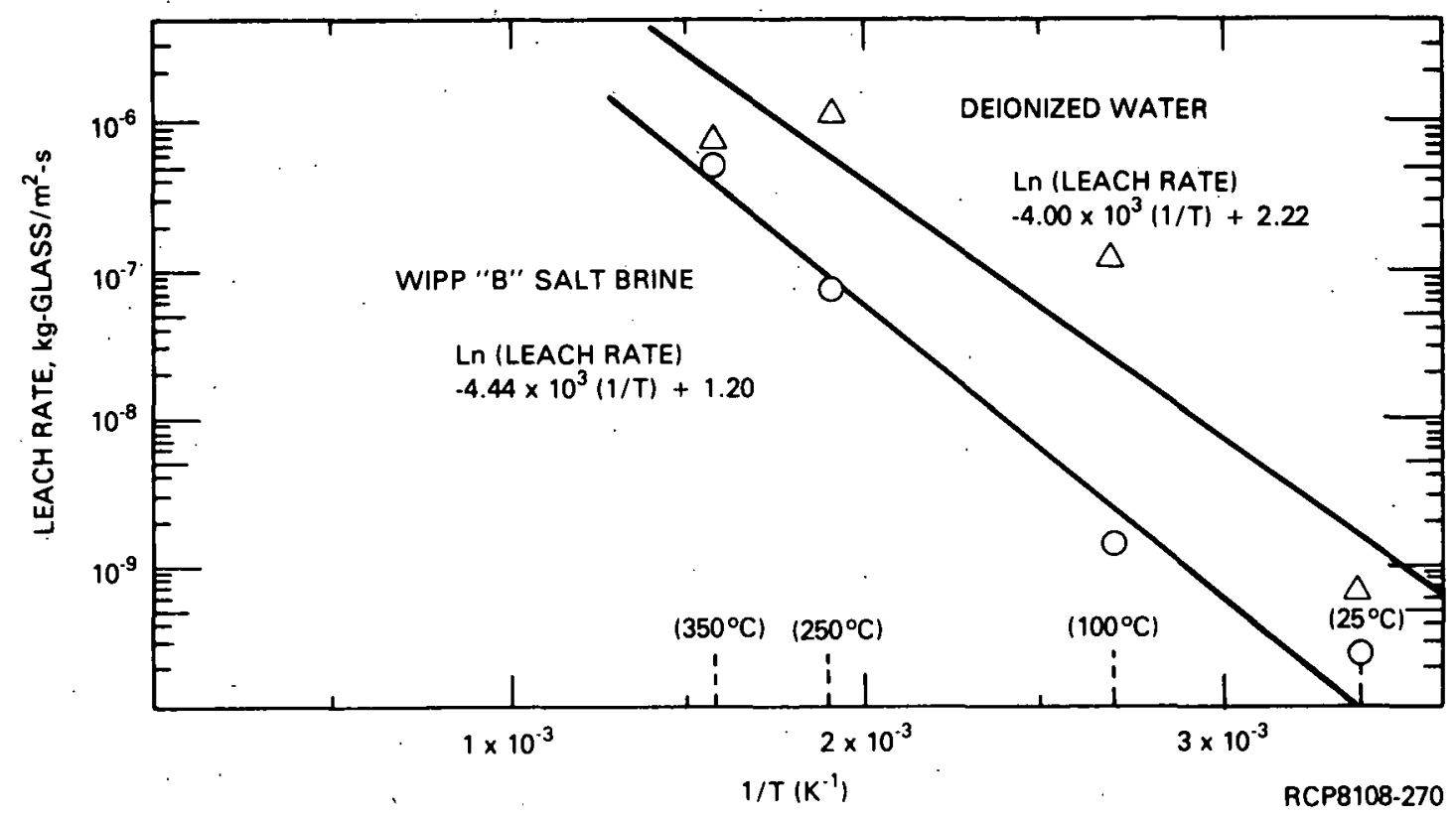

Figure 2. Effect of Temperature on 76-68 Waste Glass Leach Rates

Recently, rigorous tests have been applied to prototype waste forms that better simulate the extremes in environment that waste forms emplaced in a geologic repository may be required to withstand if the repository floods while the waste is still generating large quantities of heat. Such tests contact simulated waste forms with superheated solutions, either deionized water or simulated groundwater from candidate repository geologies. Glass waste forms alter extensively and rapidly at temperatures of $200^{\circ} \mathrm{C}$ and above and pressures of $30 \mathrm{MPa}$ (McCarthy et al., 1980; Westsik et al., 1980). A variety of accessory minerals, the result of alteration and crystallization of the glass, has been observed in the products of such experiments. For example, weeksite $\left([\mathrm{Na}, \mathrm{Cs}, \mathrm{Rb}]_{2}\left[\mathrm{UO}_{2}\right]_{2}\right.$ $\left[\mathrm{Si}_{2} \mathrm{O}_{5}\right]_{3} \cdot 4 \mathrm{H}_{2} \mathrm{O}$ ) and acmite $\left(\mathrm{NaFeSi}_{2} \mathrm{O}_{6}\right.$ ) have frequently been reported in the products of hydrothermal experiments (McCarthy et a.1., 1980; Westsik and Turcotte, 1978; Smith et a1., 1980). Many elements enter solution in appreciable amounts, as well. The results of typical hydrothermal experiments with glass are presented in Table 2. 
TABLE 2

RESIDUAL SOLUTION ANALYSES FROM HYOROTHERMAL LEACHING OF SYNTHETIC WASTE GLASS ${ }^{a}$ (After McCarthy et al., 1979a; 1980; Ross and Mende1, 1979)

\begin{tabular}{|c|c|c|c|c|c|c|c|c|}
\hline \multirow{3}{*}{ Element } & \multicolumn{4}{|c|}{$\begin{array}{l}300^{\circ} \mathrm{C}, 30 \mathrm{MPa}, 4 \text { wks, } \\
10: 1 \text { Solution-to-Glass }\end{array}$} & \multicolumn{4}{|c|}{$\begin{array}{l}350^{\circ} \mathrm{C}, 12-17 \mathrm{MPa}, 3 \text { wks, } \\
1.3: 1^{\text {Solution-to-Glass }}\end{array}$} \\
\hline & \multicolumn{2}{|c|}{ Deionized Water } & \multirow{2}{*}{$\begin{array}{c}\text { USGS } \\
\text { NBT-6a } \\
\text { Brine }\left(\begin{array}{l}c \\
d\end{array}\right)\end{array}$} & \multirow{2}{*}{$\begin{array}{l}\text { Synthetic } \\
\text { Groundwater } \\
(\mu \mathrm{g} / \mathrm{ml})\end{array}$} & \multicolumn{2}{|c|}{$\mathrm{NaCl}$ Brine } & \multicolumn{2}{|c|}{ Deionized Water } \\
\hline & $\mu \mathrm{g} / \mathrm{ml}$ & $\%$ & & & $\mu \mathrm{g} / \mathrm{ml}$ & $\%$ & $\mu \mathrm{g} / \mathrm{ml}$ & $\%$ \\
\hline $\mathrm{Na}$ & 4200 & 45 & -- & 4400 & $N R^{d}$ & -- & -- & -- \\
\hline$B$ & 2800 & 93 & 48 & 2700 & 3000 & 96 & 2500 & 86 \\
\hline $\mathrm{Si}$ & 870 & 4.6 & -- & 190 & 47 & 0.2 & 340 & 1.9 \\
\hline Mo & 1100 & 72 & 3 & 1200 & 1010 & 62 & 940 & 63 \\
\hline Cs & 49 & 5.0 & 52 & 44 & 990 & 95 & 37 & 4 \\
\hline $\mathrm{Rb}$ & 11 & 8.7 & 53 & $N D^{e}$ & 115 & 90 & 24 & 20 \\
\hline $\mathrm{Sr}$ & 0.5 & 0.15 & 49 & ND & 16.5 & 4.8 & 1.27 & 0.4 \\
\hline $\mathrm{Ba}$ & 0.5 & 0.1 & -- & 6.1 & NR & -- & NR & -- \\
\hline $\mathrm{Ca}$ & 17.4 & 1.20 & -- & $32 . \dot{2}$ & NR & -- & $\therefore$ & -- \\
\hline $\mathrm{Zn}$ & 0.2 & 0.005 & 33 & 0.4 & 13 & 0.3 & 1.6 & $<0.1$ \\
\hline $\mathrm{Ni}$ & 6.3 & 3.96 & 10.4 & ND & NR & -- & NR & - \\
\hline $\mathrm{Cr}$ & 77 & 27 & 1.1 & 132 & NR & -- & NR & -- \\
\hline $\mathrm{Fe}$ & 1 & 0.02 & 0.02 & ND & NR & -- & NR & -- \\
\hline La & 2 & 0.48 & 26 & ND & NR & -- & NR & -- \\
\hline $\mathrm{Nd}$ & ND & - & 11 & ND & NR & -- & NR & -- \\
\hline $\mathrm{Ti}$ & ND & -- & NR & ND & NR & -- & NR & -- \\
\hline $\mathrm{Zr}$ & ND & -- & 0.05 & ND & NR & -- & NR & -- \\
\hline $\mathrm{U}$ & 1.0 & 0.03 & 18 & ND & 0.5 & $<0.1$ & 8.5 & 0.2 \\
\hline
\end{tabular}

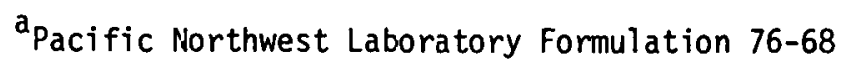

${ }^{b}$ (grams in solution/grams originally in solid) $\times 100$

${ }^{C}$ Analyzed concentrations $(\mathrm{\mu g} / \mathrm{ml}): 170 \mathrm{Na}, 60 \mathrm{Si}, 6.8 \mathrm{~K}, 0.4 \mathrm{Mg}$, no Ca detected

$\mathrm{d}_{\mathrm{NR}}=$ not reported

$\mathrm{e}_{N D}=$ not detected 
Supercalcine ceramics, coated ceramics, and SYNROC formulations have also been the subject of tests involving superheated solutions under pressure. Typically, these waste forms exhibit much less alteration than glasses under hydrothermal conditions. For example, in deionized water and silicate groundwaters, a supercalcine ceramic showed no visible reaction other than enhancement of synthetic mineral crystallinity and crystallization of residual amorphous material in the lattice when heated to $300^{\circ} \mathrm{C}$ at $30 \mathrm{MPa}$ (McCarthy et al., 1979a). Coated ceramic exposed to these solutions at $400^{\circ} \mathrm{C}$ and $30 \mathrm{MPa}$ showed no reaction. In other tests (Westsik et al., 1980), supercalcine ceramic subjected to $250^{\circ} \mathrm{C}$ and 13.8 $\mathrm{MPa}$ in deionized water developed a thin reaction layer that was depleted in cesium. No visible alteration of SYNROC B containing $9.1 \%$ waste calcine was observed in similar experiments, al though a chemical composition change was noted in the outer portions of the pellets. Data from tests of these materials are summarized in Table 3.

The stabijlity of waste forms such as these under hydrothermal conditions is partially dependent upon solution chemistry. Supercalcine ceramic, for example, is more severely leached and altered in $\mathrm{NaCl}$ brine than in deionized water or a silicate groundwater (McCarthy et al., 1979a). Glass waste forms have been reported to show less alteration in salt brine than in deionized water, al though the losses of cesium, rubidium, strontium, and molybdenum are more than an order of magnitude higher in the brine. No adequate explanation of the mechanism(s) underlying this behavior has yet been reported. Research aimed at quantifying these effects is still underway.

Recently, quantitative data on the leaching of several waste forms (glass, supercalcine ceramic, and SYNROC B containing a synthetic waste formulation) have been reported as a function of temperature (Westsik et a1., 1980). Results for many of the elements in each of these waste forms were presented. In general, the temperature dependence of leaching is greatest for glass, lower for supercalcine ceramic, and least for SYNROC. Certain groupings of relative elemental releases appear to be independent of waste form. For example, the alkali metals, 
TABLE 3

HYDROTHERMAL LEACHING DATA FOR SUPERCALCINE CERAMIC AND SYNROC CERAMIC (After McCarthy, 1979a; Westsik et al., 1980)

\begin{tabular}{|c|c|c|c|c|c|c|c|c|}
\hline \multirow[b]{3}{*}{ Element } & \multicolumn{5}{|c|}{ Supercalcine Ceramic } & \multicolumn{3}{|c|}{ SYNROC-B } \\
\hline & \multirow{2}{*}{$\underset{(\%)}{\text { Deionized Water }}$} & \multirow{2}{*}{$\begin{array}{l}\text { USGS NBT }-6 a^{a} \\
\text { Brine }(\%)\end{array}$} & \multicolumn{3}{|c|}{ Deionized Water, Frac. Leached $/ \mathrm{cm}^{2}$} & \multicolumn{3}{|c|}{ Deionized Water, Frac. Leached $/ \mathrm{cm}^{2}$} \\
\hline & & & $100^{\circ} \mathrm{C}$ & $200^{\circ} \mathrm{C}$ & $300^{\circ} \mathrm{C}$ & $100^{\circ} \mathrm{C}$ & $200^{\circ} \mathrm{C}$ & $300^{\circ} \mathrm{C}$ \\
\hline Cs & 0.5 & 38 & $2.5 E-4$ & $1.5 E-3$ & $1.8 E-3$ & $2.0 \mathrm{E}-2$ & $3.0 E-2$ & $4.0 \mathrm{E}-2$ \\
\hline $\mathrm{Sr}$ & 0.1 & 88 & $2.2 E-4$ & $8.0 \mathrm{E}-5$ & $7.0 \mathrm{E}-5$ & $2.5 \mathrm{E}-4$ & $1.8 E-5$ & $1.3 \mathrm{E}-5$ \\
\hline La & $N D^{C}$ & 2.5 & $3.5 E-5$ & $4.5 E-5$ & $6.0 \mathrm{E}-5$ & $4.0 \mathrm{E}-6$ & $6.0 \mathrm{E}-6$ & $1.3 E-5$ \\
\hline Nd & ND & 18 & $N R^{d}$ & NR & NR & NR & NR & NR \\
\hline$P$ & NR & NR & $5.2 E-4$ & $9.5 \cdot E-5$ & $1.2 \mathrm{E}-4$ & NR: & NR & NR \\
\hline $\mathrm{Na}$ & 100 & -- & $6.5 E-3$ & $1.2 \mathrm{E}-1$ & $1.5 \mathrm{E}-1$ & NR & $1.7 E-2$ & $2.2 \mathrm{E}-2$ \\
\hline $\mathrm{Rb}$ & .7 .5 & 85 & NR & NR & NR & NR. & NR & NR \\
\hline $\mathrm{Ca}$ & 0.2 & -- & $6.0 \mathrm{E}-4$ & $7.0 \mathrm{E}-5$ & $9.0 E-5$ & $N R$ & NR & NR \\
\hline $\mathrm{Ba}$ & 0.3 & 71 & NR & NR & NR & $8.0 \mathrm{E}-4$ & $2.3 E-5$ & $1.8 \mathrm{E}-5$ \\
\hline $\mathrm{Zn}$ & NP & $N P$ & NR & NR & $N R$ & NR & $9.0 E-4$ & $2.0 \mathrm{E}-4$ \\
\hline Si & 3.2 & 0.7 & $3.2 E-4$ & $2.8 E-3$ & $4.5 E-3$ & $N R$ & NR & NR \\
\hline Mo & 9.8 & 0.4 & $3.8 E-4$ & $2.3 E-3$ & $5.0 E-3$ & $4.0 \dot{E}-3$ & $5.0 E-3$ & $6.0 \mathrm{E}-3$ \\
\hline Al & NR & NR & $2.0 \mathrm{E}-4$ & $1.4 E-3$ & $1.5 E-3$ & $2.5 E-4$ & $1.0 \mathrm{E}-3$ & $1.8 \mathrm{E}-3$ \\
\hline $\mathrm{Fe}$ & ND & 0.1 & NR & NR & NR & NR & $4.6 E-4$ & $2.0 \mathrm{E}-4$ \\
\hline $\mathrm{Ni}$ & ND & 9.1 & NR & NR & NR & NR & $1.8 E-4$ & $4.6 E-4$ \\
\hline $\mathrm{Cr}$ & ND & 1.9 & $4.5 E-5$ & $1.2 \mathrm{E}-3$ & $1.3 E-2$ & $N R$ & $2.5 E-4$ & $1.2 \mathrm{E}-4$ \\
\hline
\end{tabular}

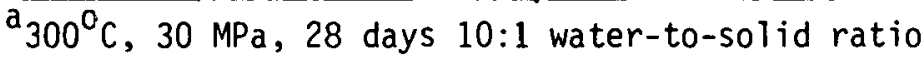

b $13.8 \mathrm{MPa}, 3$ days

$\mathrm{C}_{\mathrm{ND}}=$ not detected

$d_{N R}=$ not reported 
molybdenum, and silicon always exhibited the greatest fractional releases, while alkaline earths and rare earths consistently showed the smallest. Interestingly, at temperatures below $350^{\circ} \mathrm{C}$, these authors report inferior retention of the alkal is and molybdenum by SYNROC vis a vis supercalcine ceramic and glass. These data conflict with results reported elsewhere (Ringwood et al., 1979a; 1979b). The presence of waste in this latter case was simulated by doping a SYNROC mineral assemblage with $1 \%$ cesium, $1 \%$ strontium, and $1 \%$ uranium in an unspecified manner. This method of waste addition provides, at best, an incomplete simulation of the actual, highly complex composition of nuclear waste from a fuel reprocessing plant. Although very low leaching rates are claimed, the absence of actual data in these reports by the developers of SYNROC makes meaningful comparisons difficult.

The examples presented in this section demonstrate the interplay of the many variables that affect the leaching of prototype waste forms. The general question of waste-form durability. is complex and is only now being quantified to any degree. The presence of additional materials in the system, such as an abundance of repository host rock, adds still more complexity to the problem. 


\section{WASTE-FORM/HOST-ROCK/GROUNDWATER INTERACTIONS}

Although leaching experiments such as those described in the previous section allow the relative stabilities of various waste forms to be determined under a variety of conditions, they do not give a definitive picture of reactions that may take place among all materials - waste form, groundwater, host mineralogy, canister, manmade or added barrier materials - likely to be present in the repository. Experiments that include materials other than just the waste form and water, al though more complex to perform and interpret, allow measurement of the chemical effects that the rock mass, for example, will have upon the system. Detrimental reactions (such as accelerated leaching of the waste form or increased nuclide mobility), which may be due to the presence of the rock, or beneficial reactions (such as precipitation of highly stable minerals containing leached radionuclides) may be studied if experiments include a more complete suite of materials. Naturally, such experiments depend upon an adequate foundation of leaching data (leach rates, mechanisms) from waste-form/water experiments to allow the best interpretation of the data.

The data available from reactions of various ceramic waste forms with both groundwater and rock from the various candidate repository geologies are either very 1 imited or nonexistent. The first such experiments were reported in mid-1978 (McCarthy et al., 1978) in the open literature. Only data from reactions of glass, supercalcine ceramic, and simulated spent fuel with groundwater and repository rock at temperatures and pressures likely to be present in a young geologic repository have been reported to date. Virtually all such experiments have been performed with simulations of waste forms containing postulated reprocessing wastes from commercial power fuels. Little or no work has been reported for experiments with rocks such as tuff or granite. The bulk of the waste/rock/ water reaction experiments have been performed with basalt from the Columbia Plateau or heavily saturated brines typical of those that may be present in a salt repository. Some experiments have also been performed with shale. Consequentiy, a large body of work remains to be accomplished. 
Most experiments in which waste forms, rock, and groundwater have been reacted together have been performed in some sort of high-pressure apparatus. Static tests, for example, have typically been performed in sealed gold capsules using cold-seal pressure vessels (e.g., McCarthy et al., 1979a) to control temperature and pressure. Such tests require depressurization and quenching before analyses can be performed. Other types of experimental apparatus. that allow a single pass of solution past the rock and waste form, maintained at appropriate temperatures and pressures such as may occur in a flooded repository or that allow sampling of the solution during the experiment are underway: However, no results have been reported for these investigations.

Waste/rock/groundwater reaction experiments have usually been performed at temperatures of 100 to $300^{\circ} \mathrm{C}$. These temperatures represent the range expected during the time period in which the waste contributes significant amounts of heat to the repository environment (Coons, 1980). In a repository in basalt, the maximum temperature at the waste package-rock interface is expected to be about $270^{\circ} \mathrm{C}$ (for spent fuel). Peak temperatures are higher and occur sooner near the waste package (Smith et al., 1980). Due to the low thermal conductivity of basalt and a decreasing thermal power output from the waste (again, spent fuel), the bulk of the rock within the repository will reach a maximum (repository centerline) temperature of 180 to $200^{\circ} \mathrm{C}$. Similar centerline temperatures have been predicted $\left(\sim 220^{\circ} \mathrm{C}\right)$ for a young repository in the Eleana argillite, a shale (Eaton et al., 1980). Some experiments have been conducted at 400 and $500^{\circ} \mathrm{C}$, allowing examination of the potential effects of local temperature excursions should they occur. Al though temperatures of even $300^{\circ} \mathrm{C}$ may not occur, experiments at such elevated temperatures accelerate reactions sufficiently for slow processes to be observed. Whether all such experiments may be directly extrapolated to predict reactions at lower temperatures is debatable. For example, such extrapolation is not valid when a mineral stability boundary lies between the temperature of the experiment and the temperature of interest. The temperature in a repository will vary as a function of time, and the actual peak temperatures achieved are dependent upon variables such as the thermal power of the canister, the thermal conductivity of the rock, canister emplacement density, etc.

DOE/ET/41900-13

(ESG-DOE-13364) 
Similarly, the pressure experienced by emplaced waste is a function of several variables and will change as a function of time. Before closure, the repository pressure will be $0.1 \mathrm{MPa}$ (atmospheric pressure). In basalt, a pressure of $10 \mathrm{MPa}$ may be expected in a flooded repository at a $1000-\mathrm{m}$ depth if only hydrostatic pressure is reestablished. If the lithostatic load is reestablished, a pressure of $30 \mathrm{MPa}$ will be present in the repository system (Smith et al., 1980). Pressures in this range have been used in most waste/rock/groundwater reaction experiments (typically hydrothermal water pressure, but sometimes applied using such gases as argon or nitrogen). Other factors may raise the repository pressure to the level of lithostatic loads or even higher, as discussed by Eaton et al. (1980) in estimates for a conceptual repository in Eleana argillite. If, for example, a "perfect" backfill is employed (permeability $=10^{-7}$ darcy, that of the shale itself), a maximum fluid pressure of $77 \mathrm{MPa}$ may be encountered. Wasteform durability tests that iniclude the host rock have not yet been reported at such high pressures.

As discussed in the previous section, current prototype waste forms undergo varying degrees of alteration when reacted with deionized water or synthetic groundwater at elevated temperature and pressure. Most of the radionuclides removed enter the solution and are, therefore, potentially mobile. When specimens of repository host rock are added to the systems, significant changes are observed (McCarthy et al., 1980; Scheetz et al., 1980). In many cases, radionuclides that were extracted into the solution in waste-form/water reactions are immobilized as new minerals formed in the waste-form/rock/water system, either. at temperature or upon quenching, and lower concentrations of leached ions in solution are observed.

Preliminary studies of the reaction of borosilicate glass waste forms with basalt and shale in the presence of water have been reported by various researchers (McCarthy et a1., 1978; 'Ross and Mende1, 1979; Freeborn et al., 1980;

Scheetz et al., 1980; Coons et al., 1980). At 200 to $300^{\circ} \mathrm{C}$ and 30 MPa, borosilicate glass is extensively altered in the presence of deionizing water or simulated groundwater (McCarthy et al., 1980).

DOE/ET/41900-13

(ESG-DOE-13364) 
Different researchers have reported results from reactions of borosilicate glass, basalt, and water that appear to be in conflict (see Table 4). Investigators at Pacific Northwest Laboratory reported significant decreases in the quantity of dissolved elements present in solution when Umtanum basalt was reacted at $350^{\circ} \mathrm{C}$ and $12-17 \mathrm{MPa}$ in water with glass, compared to results obtained with glass and water alone (Ross and Mende1, 1979). Other investigators. (Scheetz et al., 1980) reported small increases in the concentrations of various elements in solution in similar experiments at $300^{\circ} \mathrm{C}$ and $30 \mathrm{MPa}$. One explanation offered for this discrepancy was the different water-to-rock ratios in the two sets of experiments, 1.3:1 in the former case and 10:1 in the latter (Coons et al,, 1980). The former case may be considered representative of a flooded repository backfilled with basalt with little or no flow. In the latter case, which may be taken to represent water moving through the repository at a rapid rate, a $\mathrm{pH}$ depression similar to that observed in basalt/seawater reaction experiments (Bischoff and Dickson, 1976) may have occurred early in the experiment. Such conditions are favored by the high water-to-solids ratio of these experiments and are known to accelerate the leaching of glass. However, differences in reaction conditions (noted above) and basalt specimens from different sources may also have accounted for a significant portion of the discrepancy. It is interesting to note that after 4 month' ' exposure of BCR-1 basalt and 76-68 glass at $300^{\circ} \mathrm{C}$ and $30 \mathrm{MPa}$ with twice as much water, Scheetz and coworkers (1980) reported only minor changes for most of the elements in solution from the 4-week, 10:1 water-to-rock ratio experiments discussed above.

Mineral phases formed as a result of the interaction of waste glass and basalt in superheated water have also been reported (Scheetz et al., 1980). Two phases observed in the products of hydrothermal reactions between glass waste forms and water, acmite and acmite-augite ( $[\mathrm{Na}, \mathrm{Ca}][\mathrm{Fe}, \mathrm{Zn}, \mathrm{Ti}] \mathrm{Si}_{2} \mathrm{O}_{6}$ ), also resulted from reactions of basalt, waste glass (PNL 76-68), and water at 200 or $300^{\circ} \mathrm{C}$ and $30 \mathrm{MPa}$ for various periods of time. In experiments lasting 4 months, quartz, pollucite $\left(\mathrm{CsAlSi}_{2} \mathrm{O}_{6}\right)$, orthoclase $\left(\mathrm{KAISi}_{2}{ }_{6}\right)$, and the zinc silicate willemite $\left(\mathrm{Zn}_{2} \mathrm{SiO}_{4}\right)$ were also observed. Weeksite, which formed in experiments with glass and water alone, was only seen in experiments in which chunks of 
TABLE 4

RESIDUAL SOLUTION COMPOSITIONS FROM HYDROTHERMAL REACTIONS OF PACIFIC NORTHWEST L'ABORATORY 76-68 GLASS WITH BASALT AND. DISTILLED WATER (After Sheetz et a1., 1980; Ross and Mende1, 1979;. Westsik and Turcotte, 1978)

\begin{tabular}{|c|c|c|c|c|c|}
\hline \multirow[b]{2}{*}{ Element } & \multirow[b]{2}{*}{ Water-Rock ${ }^{a}$} & \multicolumn{2}{|c|}{ Element in Solution ${ }^{b}(\%)$} & \multirow{2}{*}{$\begin{array}{l}\text { Net Change } \\
(\%)\end{array}$} & \\
\hline & & Glass & Glass + Basalt & & \\
\hline $\mathrm{Rb}$ & $\begin{array}{l}10: 1 \\
20: 1 \\
1.3: 1\end{array}$ & $\begin{array}{l}8.7 \\
2 \\
20\end{array}$ & $\begin{array}{l}14 \\
17 \\
0.06\end{array}$ & $\begin{array}{l}+5.3 \\
+15 \\
-19.94\end{array}$ & \\
\hline Cs & $\begin{array}{l}10: 1 \\
20: 1 \\
1.3: 1\end{array}$ & $\begin{array}{r}5 \\
14 \\
4\end{array}$ & $\begin{array}{l}20.3 \\
20 \\
0.04 .\end{array}$ & $\begin{array}{l}+15.3 \\
+6 \\
-4.96\end{array}$ & \\
\hline$s r$ & $\begin{array}{l}10: 1 \\
20: 1 \\
1.3: 1\end{array}$ & $\begin{array}{c}0.15 \\
\text { ND } \\
0.4\end{array}$ & $\begin{array}{l}\mathrm{ND}^{\mathrm{C}} \\
0.4 \\
0.05\end{array}$ & $\begin{array}{l}-0.15 \\
+0.4 \\
-0.35\end{array}$ & \\
\hline B & $\begin{array}{l}10: 1 \\
20: 1 \\
1.3: 1\end{array}$ & $\begin{array}{l}93 \\
80 \\
86\end{array}$ & $\begin{array}{l}91 \\
88 \\
5.9\end{array}$ & $\begin{array}{l}-2 \\
+8 \\
-80.1\end{array}$ & $\cdots$ \\
\hline Mo & $\begin{array}{l}10: 1 \\
20: 1 \\
1.3: 1\end{array}$ & $\begin{array}{l}72 \\
68 \\
63\end{array}$ & $\begin{array}{l}85 \\
59 \\
0.05\end{array}$ & $\begin{array}{l}+13 \\
-9 \\
-62.95\end{array}$ & \\
\hline $\begin{array}{l}U \\
.\end{array}$ & $\begin{array}{l}10: 1 \\
20: 1 \\
1.3: 1\end{array}$ & $\begin{array}{c}0.03 \\
N J \\
0.2\end{array}$ & $\begin{array}{l}0.05 \\
N D \\
0.002\end{array}$ & $\begin{array}{l}+0.02 \\
-0.198\end{array}$ & \\
\hline $\mathrm{Si}$ & $\begin{array}{l}10: 1 \\
20: 1 \\
1.3: 1\end{array}$ & $\begin{array}{l}4.6 \\
2.3 \\
1.9\end{array}$ & $\begin{array}{l}1.0 \\
1.5 \\
0.07\end{array}$ & $\begin{array}{ll}- & 3.6 \\
- & 0.8 \\
- & 1.83\end{array}$ & \\
\hline
\end{tabular}

$\mathrm{a}_{10: 1}$ and $20: 1$ water-rock ratios, $\mathrm{T}=300^{\circ} \mathrm{C}, \mathrm{P}-30 \mathrm{MPa}$, duration $=28$ days and 4 months, respectively, BCR-1 basalt; $1.3: 1$ water-rock ratio, $T=350^{\circ} \mathrm{C}$, $\mathrm{P}=12.1-17.3 \mathrm{MPa}$, duration $=21$ days, Umtanum basalt

b (grams in solution/grams originally in solid) $\times 100$

$\mathrm{C}_{\mathrm{ND}}=$ none detected 
glass and basalt were reacted. When powdered materials were used, providing a closer, more rapid approach to equilibrium conditions, weeksite was not observed, and an unidentified phase containing calcium, zinc, iron, and silicon was always present. This phase appeared to be similar to verplanckite ( $\mathrm{Ca}_{2}[\mathrm{Mn}, \mathrm{Zn}, \mathrm{Fe}, \mathrm{Ti}]$ $\left.\mathrm{Si}_{2} \mathrm{O}_{6}[\mathrm{O}, \mathrm{OH}]_{2} \cdot 3 \mathrm{H}_{2} \mathrm{O}\right)$, al though it has not yet been positively identified. The results suggest that weeksite will be unstable at the equilibrium oxygen fugacity established by the basalt. In basalt systems, which are strongly reducing, the stable phase containing uranium is likely to be $\mathrm{UO}_{2}$ (Rich et al., 1977; Langmuir, 1978). Experiments similar to those described above but run at $100^{\circ} \mathrm{C}$ produced little evidence of reaction-phase formation. However, results obtained by Westsik et a1. (1980) and other observations (Smith et al., 1980) indicate that reaction products will. probably appear after much longer interaction times at this temperature. Such long reaction times are an unavoidable characteristic of a geologic repository that floods early in its operational lifetime (after closure).

Samples of shale from several different sources have been reacted with waste glass (and ceramics, as will be discussed shortly), providing results that in many respects are similar to those described above for glass/water/basalt reactions (Freeborn et al., 1980). For example, weeksite, willemite, and pollucite are also seen in waste glass/shale/water reactions. Other phases observed

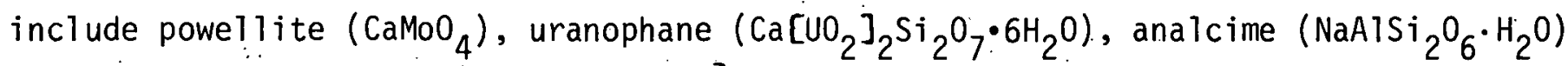
and sauconite $\left(\mathrm{Na}_{0.33} \mathrm{Zn}_{3}[\mathrm{Al}, \mathrm{Si}]_{4} \mathrm{O}_{10}[\mathrm{OH}]_{2} \cdot 4 \mathrm{H}_{2} \mathrm{O}\right)$, containing, as in willemite, zinc extracted from the glass. Differences in the reaction phases observed can be readily correlated with composition variations between different shales. For instance, weeksite was not produced when glass was reacted with Atrim shale, which is highly reducing. New crystalline phases were formed in reactions conducted at 200,300 , and $400^{\circ} \mathrm{C}$, with extensive interaction occurring at 300 and $400^{\circ} \mathrm{C}$. At these higher temperatures, the principal shale minerals, quartz and clays, are also altered, recrystallizing as micas and feldspars. The aluminosilicate minerals act as scavengers in such reactions, immobilizing cesium, strontium, and other released radionuclides in mineral form. Most of. the radionuclides that enter the solution appear to be fixed in new minerals formed by waste/shale/water interaction (McCarthy et al., 1979a).

DOE/ET/41900-13

(ESG-DOE-13364) 
A few experiments have been performed in which rock salt from a potential repository site (the Waste Isolation Pilot Plant, or WIPP) was reacted with water and glass waste forms. The experiment produces a brine much like those used in the simulated groundwater/waste interaction experiments, with results very similar to those presented in Table 2. The only new phase observed in such tests has been acmite (Westsik and Turcotte, 1978; Ross and Mendel, 1979).

The waste/rock/groundwater reaction experiments performed to date with glass waste forms can provide useful information about repository interactions that may also affect crystalline ceramic waste forms. Many ceramic waste forms, such as supercalcine ceramic, may contain small quantities (up to $15 \%$ vol $\%$ ) of vitreous materials (McCarthy et al., 1979b; Harker et al., 1980b) in grain boundary regions. Glass-ceramic waste forms may contain as much as 50 vol \% vitreous material (Rusin, 1980). Some radionuclides are likely to remain in the glassy phase rather than entering the desired crystalline structure and will thus be more vulnerable to leaching under hydrothermal conditions in the repository system. In such a case, the formation of minerals similar to those observed in the glass/water/rock experiments described above may be expected.

Experiments with glass waste forms also permit a preliminary estimate of which secondary phases are likely to form should specific phases in a ceramic waste form fail under prolonged exposure to hydrothermal conditions. Currently, results from reactions of crystalline ceramic waste forms in candidate repository environments are rather 1 imited. Although a number of tests have been performed on ceramic waste forms to date, the low reaction rates observed (in most cases) and the relatively short duration of the experiments (up to 4 months) do not allow prediction of a ceramic's overall long-term performance with absolute confidence. Additional experiments of much longer duration are required for such predictions. The rapid reaction of glass waste forms in superheated water in the presence of rock allows projections to be made somewhat more simply.

Of the proposed crystalline ceramic waste forms, only supercalcine ceramic has been reacted with repository host-rock specimens and superheated groundwater. Its stability has been tested in the presence of both basalt and shale, as well as DOE/ET/41900-13

(ESG-D0E-13364) 
in saturated brines produced by combining a large mass of salt (relative to the amount of waste form) and water in the reaction vessel. In general, only 1 imited reactions have been observed in hydrothermal reactions of supercalcine ceramic, repository host rock, and water (McCarthy et a1., 1979b). In silicate groundwater systems (basalt and shale), no alteration products are detected at $100^{\circ} \mathrm{C}$ and $30 \mathrm{MPa}$ (Freeborn et al., 1980; Komarneni et a1., 1980a). Very little change was observed in the solid or 7 iquid phases at even $200^{\circ} \mathrm{C}$ in reactions with basalt (Coons et al., 1980) and shale. At $300^{\circ} \mathrm{C}$ and $30 \mathrm{MPa}$, small amounts of rubidium, sodium, molybdenum, and silicon have been observed to enter solution, along with traces of cesium, strontium, barium, and calcium (McCarthy et al, 1979b). These are fixed, in general, as minerals resulting from the interactions. In reactions with basalt, these products included pollucite, powellite, weeksite, haiweeite $\left.\left(\mathrm{Ca}_{\mathrm{UO}_{2}}\right]_{2}\left[\mathrm{Si}_{2} \mathrm{O}_{5}\right]_{3} \cdot \mathrm{nH}_{2} \mathrm{O}\right)$, apatite $\left(\mathrm{Ca}_{5}\left[\mathrm{PO}_{4}\right]_{3} \mathrm{OH}\right)$, and some zeolites. The quantity of new minerals formed was relatively sma11. In this case, too, the presence of basalt appears to stabilize uranium even under oxidizing conditions. In addition, the crystallinity of the sythetic minerals in the supercalcine ceramic was apparently enhanced, and the amorphous phase present in the matrix was crystallized by the hydrothermal solutions. Analyses of the solutions resulting from such experiments (Smith et al., 1980) are presented in Table 5.

Reactions of a supercalcine ceramic in a saturated bittern brine (McCarthy et a]., 1979a; 1979b) such as may be present in a repository in salt were much less favorable. Major amounts $(>10 \%)$ of the cesium, strontium, rubidium, barium, nickel, and lanthanides originally contained in the waste form were reportedly extracted into solution, along with minor amounts of chromium and silicon $(0.5$ to $9.0 \%$ of the amounts originally contained) and a trace of iron. Some alteration of the crystalline phases in the waste form was observed, and some new phases were reported to have formed, although these were not identified. Other investigators (Westsik and Turcotte, 1978) report formation of the phase $\mathrm{Ca}_{0.1} \mathrm{Sr}_{0.8} \mathrm{Ba}_{0.1} \mathrm{MoO}_{4}$ on the surface of a supercalcine ceramic that had been reacted with a saturated $\mathrm{NaCl}$ brine. Solution chemistries typical of such reactions were presented in Table 3. 
TABLE 5

RESIDUAL. SOLUTION COMPOSITIONS FROM HYDROTHERMAL REACTIONS ${ }^{a}$ OF SUPERCALCINE CERAMIC SPC-4 AND BASALT IN WATER (After Smith et al., 1980)

\begin{tabular}{|c|c|c|c|c|c|c|}
\hline \multirow[b]{2}{*}{ Element } & \multirow[b]{2}{*}{$\begin{array}{c}\text { Temperature } \\
\left({ }^{C} \mathrm{C}\right)\end{array}$} & \multicolumn{2}{|c|}{ SPC-4 Ceramic } & \multicolumn{3}{|c|}{ SPC-4 Ceramic + Basalt } \\
\hline & & $\mu \mathrm{g} / \mathrm{ml}$ & $\%^{b}$ & $\mathrm{\mu g} / \mathrm{ml}$ & $\%^{b}$ & \\
\hline $\mathrm{Rb}$ & $\begin{array}{l}200 \\
300\end{array}$ & $\begin{array}{l}30 \\
25\end{array}$ & $\begin{array}{l}0.5 \\
4.6\end{array}$ & ${ }_{N D^{C}}^{30}$ & 0.6 & \\
\hline Cs & $\begin{array}{l}200 \\
300\end{array}$ & $\begin{array}{l}10 \\
25\end{array}$ & $\begin{array}{l}0.2 \\
0.6\end{array}$ & $\begin{array}{r}10 \\
9\end{array}$ & $\begin{array}{l}0.2 \\
0.4\end{array}$ & \\
\hline$S r$ & $\begin{array}{l}200 \\
300\end{array}$ & $\begin{array}{l}0.5 \\
2.3\end{array}$ & $\begin{array}{l}0.01 \\
0.06\end{array}$ & $\begin{array}{l}0.1 \\
--\end{array}$ & 0.1 & \\
\hline Mo & $\begin{array}{l}200 \\
300\end{array}$ & $\begin{array}{r}83 \\
370\end{array}$ & $\begin{array}{l}1.5 \\
6.8\end{array}$ & $\begin{array}{r}100 \\
13\end{array}$ & $\begin{array}{l}1.8 \\
0.5\end{array}$ & \\
\hline La & $\begin{array}{l}200 \\
300\end{array}$ & $\begin{array}{l}\text { ND } \\
\text { ND }\end{array}$ & -- & $\begin{array}{l}\text { ND } \\
\text { ND }\end{array}$ & -- & 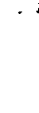 \\
\hline $\mathrm{Nd}$ & $\begin{array}{l}200 \\
300\end{array}$ & $\begin{array}{l}\text { ND } \\
\text { ND }\end{array}$ & - & $\begin{array}{l}\text { ND } \\
\text { ND }\end{array}$ & -- & \\
\hline
\end{tabular}

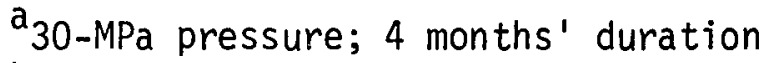

${ }^{b}$ (amount in solution/amount originally in solids) $\times 100$

${ }^{\mathrm{C}} \mathrm{ND}=$ not detected by atomic absorption, atomic emission, or fluorometry 
Supercalcine cores coated with successive layers of pyrolytic carbon and $\mathrm{Al}_{2} \mathrm{O}_{3}$ (Rusin et al., 1979) have also been subjected to hydrothermal attack in the presence of basalt and saturated bittern brines (McCarthy et al., 1979b) at 300 and $400^{\circ} \mathrm{C}$ and $30 \mathrm{MPa}$. In these reactions, no detectable waste/rock interaction effects such as new phase formation or elements leached into solution were observed from intact samples (no coating flaws). Even in bittern brine, only minor recrystallization of the outer $\mathrm{Al}_{2} \mathrm{O}_{3}$ coating was observed.

Some work on the stability of individual ceramic phases in contact with superheated groundwater and repository rock has been conducted, mostly in connection with studies of spent-fuel stabilities in repository environments (e.g., Komarneni et a.., 1980b). Some of the phases that have been studied are quite similar to phases proposed for inclusion in prototype ceramic. waste forms such as SYNROC or Tailored Ceramic. For example, the hydrothermal reaction of $\mathrm{SrZrO}_{3}$ with basalt or individual basalt mineral phases produced no new recrystallization phases (Komarneni, et al. 1980b). Approximately. $1 \%$ of the available strontium in $\mathrm{SrZrO}_{3}$ entered solution in these 1-to-2-month tests. Nesbitt et al. (1980) have determined that perovskite $\left(\mathrm{CaTiO}_{3}\right)$ is unstable in groundwaters that contain quantities of dissolved $\mathrm{CO}_{2}$ and $\mathrm{SiO}_{2}$ similar to those present in the groundwaters of siliceous rocks (basalt, shale, etc.). Hydrothermal leach testing of perovskite by these investigators revealed significant leachabilities even at $100^{\circ} \mathrm{C}$ and suggested that $\mathrm{CaTiO}_{3}$ is less stable in carbonate/silicate groundwaters at this low temperature than at $300^{\circ} \mathrm{C}$. These authors also suggested that based on geologic evidence, the SYNROC phases hollandite $\left(\mathrm{BaAl}_{2} \mathrm{Ti}_{6}{ }^{0}{ }_{16}\right)$ and zirconolite $\left(\mathrm{CaZrTi}_{2} \mathrm{O}_{7}\right)$ will not survive mild hydrothermal reactions in common alkaline rock matrices.

The relatively limited scope of the waste/rock/groundwater reaction experiments performed to date should be readily apparent from the foregoing discussion. Although many experiments have been performed in the past 3 years, reactions of waste forms with granite (a leading candidate for repository emplacement) or tuff have not been reported. Studies of variables other than temperature and 
pressure in a single system have also been limited. Even in the case of temperature and pressure variations, further work appears to be necessary to achieve good quantitative predictions of long-term waste-form behavior in a repository system. The results of such experimental programs will influence the development of engineered-barrier systems, indicating whether such systems are indeed required and suggesting what materials might be effective barriers. Standardization of experimental techniques will aid this effort and will allow the effects of variables such as the solution-to-solid ratio (as discussed above) and different reaction-container materials (such as sealed unreactive gold tubing vs Hasteloylined reaction vessels that induce an artificial reduction in oxygen fugacity during the experiment) to be fully accounted for. Waste form/repository environment reaction tests are required complements to geochemical predictions, which do not necessarily account for the complex chemistry of the nuclear waste or waste form.

Once some of the variables that influence waste form dissolution are more thoroughly understood and prototype engineered barriers have been devised, hydrothermal tests that include these manmade materials will be required. Such experiments should reveal any adverse effects produced by the canister material and other materials intended to offset waste-form weaknesses in the repository environment. 


\section{iv. SORPTION}

Should reactions among the waste form, the barrier system, the host rock, and the groundwater result in radionuclides entering solution and being carried away from the canisters, the radionuclide-bearing solution will eventualiy enter areas containing only the repository host rock. Although the manmade barriers will be designed to contain most (if not a 11 ) radioactive species, it is assumed here that some will remain in the groundwater. Once groundwater containing leached radionuclides exits from the repository zone, the sorptive and ion-exchange capacities of the host rock (and of other minerals in the solution pathway) constitute the final barrier preventing radionuclide release to the biosphere.

The release rate and groundwater-borne migration rate of leached radionuclides through the host rock will be influenced by wasteform durability, groundwater flow rate and volume, sorptive capacity of the host rock, and groundwater chemistry ( $\mathrm{pH}$, Eh, ionic strength, etc.). Unfortunately, none of these characteristics can be defined without reference to another set of complex interactions. For instance, the sorptive capacity is influenced by factors such as host-rock mineralogy and surface area, groundwater flow rate and volume, temperature, and groundwater chemistry.

In an earlier report on host-rock characteristics, the authors (Johnston and Palmer, 1981) summarized a portion of the available sorption data for various candidate repository geologies. Those data will be presented here.

Representative sorption data for basaltic rocks and secondary minerals found in basalt formations are presented in Table 6 . As is evident from the data, the relationships between the sorptive capacity of a material and the various physical parameters of the experiment (time, temperature, $\mathrm{pH}$, Eh, etc.) are complex and not always predictable. Thus, in order to make valid comparisons (or predictions) of sorptive behavior, it is imperative that the experimental techniques used to obtain the data be known in as much detail as possible. 
TABLE 6

SORPTION OF SELECTED RADIONUCLIDES BY UMTANUM BASALT AND BASALT SECONDARY MINERALS FROM SYMTHETIC GRANDE RONDE GROUNDWATER (After Smith et a1., 1980)

\begin{tabular}{|c|c|c|c|c|c|c|c|c|c|c|}
\hline \multirow[b]{3}{*}{ Radionuclide } & \multicolumn{5}{|c|}{ Crushed Umtanum Basalt } & \multicolumn{5}{|c|}{ Basalt Secondary Minerals } \\
\hline & \multirow[b]{2}{*}{$\mathrm{pH}$} & \multirow{2}{*}{$\left.i^{0} \mathrm{C}\right)$} & \multirow{2}{*}{$\begin{array}{l}\text { Equilibration } \\
\text { Time (days) }\end{array}$} & \multicolumn{2}{|c|}{$\mathrm{R}_{\mathrm{d}}(\mathrm{ml} / \mathrm{g})^{\mathrm{a}}$} & \multirow[b]{2}{*}{$\mathrm{pH}$} & \multirow{2}{*}{$\left({ }^{0} \mathrm{C}\right)$} & \multirow{2}{*}{$\begin{array}{l}\text { Equilibration } \\
\text { Time (days) }\end{array}$} & \multicolumn{2}{|c|}{$R_{d}(m l / g)$} \\
\hline & & & & $0 \times$ ic $^{b}$ & Anoxic ${ }^{C}$ & & & & oxic & Anoxic \\
\hline $\mathrm{Cs}$ & $\begin{array}{l}8.15 \\
8.90\end{array}$ & $\begin{array}{l}23 \\
60\end{array}$ & $\begin{array}{l}83 \\
59\end{array}$ & $\begin{array}{r}1,700 \\
550\end{array}$ & $\begin{array}{l}N^{d} \\
N R\end{array}$ & $\begin{array}{l}8.50 \\
8.50\end{array}$ & $\begin{array}{l}23 \\
60\end{array}$ & $\begin{array}{l}57 \\
67\end{array}$ & $\begin{array}{l}70,000 \\
17,000\end{array}$ & $\begin{array}{l}\text { NR } \\
\text { NR }\end{array}$ \\
\hline $\mathrm{Sr}$ & $\begin{array}{l}8.40 \\
8.95\end{array}$ & $\begin{array}{l}23 \\
60\end{array}$ & $\begin{array}{l}83 \\
59\end{array}$ & $\begin{array}{l}103 \\
240\end{array}$ & $\begin{array}{l}\text { NR } \\
\text { NR }\end{array}$ & $\begin{array}{l}8 . \dot{55} \\
8.80\end{array}$ & $\begin{array}{l}23 \\
60\end{array}$ & $\begin{array}{l}67 \\
67\end{array}$ & $\begin{array}{l}480 \\
250\end{array}$ & $\begin{array}{l}\text { NR } \\
\text { NR }\end{array}$ \\
\hline $\mathrm{Se}$ & $\begin{array}{l}8.90 \\
8.45\end{array}$ & $\begin{array}{l}23 \\
60\end{array}$ & 83, $60^{\mathrm{e}}$ & $\begin{array}{r}4 \\
10\end{array}$ & $\begin{array}{l}17 \\
\text { NR }\end{array}$ & $\begin{array}{l}8.50 \\
8.75\end{array}$ & $\begin{array}{l}23 \\
60\end{array}$ & 67,60 & $\begin{array}{l}0 \\
0\end{array}$ & $\begin{array}{r}3 \\
N R\end{array}$ \\
\hline I & $\begin{array}{l}8.95 \\
8.80\end{array}$ & $\begin{array}{l}23 \\
60\end{array}$ & $\begin{array}{l}83 \\
59\end{array}$ & $\begin{array}{l}3.1 \\
0\end{array}$ & $\begin{array}{l}\text { NR } \\
\text { NR }\end{array}$ & $\begin{array}{l}8.50 \\
8.60\end{array}$ & $\begin{array}{l}23 \\
60\end{array}$ & $\begin{array}{l}67 \\
67\end{array}$ & $\begin{array}{c}2.3 \\
0\end{array}$ & $\begin{array}{l}\text { NR } \\
\text { NR }\end{array}$ \\
\hline Tc & $\begin{array}{l}9.0 \\
8.35\end{array}$ & $\begin{array}{l}23 \\
60\end{array}$ & $\begin{array}{c}83,60 \\
59\end{array}$ & $\begin{array}{l}12 \\
40\end{array}$ & $\begin{array}{l}4,000 \\
\text { NR }\end{array}$ & $\begin{array}{l}8.30 \\
8.50\end{array}$ & $\begin{array}{l}23 \\
60\end{array}$ & $67, \quad 50$ & $\begin{array}{l}0 \\
0\end{array}$ & $\begin{array}{r}0 \\
\text { NR }\end{array}$ \\
\hline $\mathrm{Np}$ & $\begin{array}{l}8.50 \\
8.80\end{array}$ & $\begin{array}{l}23 \\
60\end{array}$ & 83,60 & $\begin{array}{r}9 \\
13\end{array}$ & $\begin{array}{l}150 \\
\text { NR }\end{array}$ & $\begin{array}{l}8.28 \\
8.60\end{array}$ & $\begin{array}{l}23 \\
60\end{array}$ & $67, \frac{60}{67}$ & $\begin{array}{r}9 \\
11\end{array}$ & $\begin{array}{l}79 \\
\text { NR }\end{array}$ \\
\hline $\mathrm{Ra}$ & $\begin{array}{l}7.85 \\
8.45\end{array}$ & $\begin{array}{l}23 \\
60\end{array}$ & $\begin{array}{r}8 \\
59\end{array}$ & $\begin{array}{l}64 \\
66\end{array}$ & $\begin{array}{l}\text { NR } \\
\text { NR }\end{array}$ & $\begin{array}{l}8.30 \\
8.35\end{array}$ & $\begin{array}{l}23 \\
60\end{array}$ & $\begin{array}{l}67 \\
67\end{array}$ & $\begin{array}{l}100 \\
180\end{array}$ & $\begin{array}{l}\text { NR } \\
\text { NR }\end{array}$ \\
\hline
\end{tabular}

$a_{R_{d}}=$ radionuclide concentration in solid per $\mathrm{g} /$ radionuclide concentration in liquid per $\mathrm{m} l$ (also call $k_{d}$ )

$\mathrm{b}_{0 x i c}=$ experiments in air, $0_{2}$ partial pressure $\sim 0.2 \mathrm{~atm}$

${ }^{\mathrm{C}}$ Anoxic $=\mathrm{O}_{2}$ partial pressure $.7 .87 \times 10^{-7} \mathrm{~atm}$

$\mathrm{d}_{\mathrm{NR}}=$ not reported

${ }^{\mathrm{e}}$ Second time, if reparted, is for anoxic $R_{d}$ experiment 
Bearing in mind the above qualification, a number of conclusions may be drawn from existing data concerning the sorptive capacity of basalt and secondary minerals in basalt. (Secondary minerals - clays, zeolites, quartz, etc. - result from groundwater attack on the primary minerals and amorphous material present in basaltic rocks. For further details, see Johnston and Palmer, 1981.) In general, the sorptive capacity of the secondary minerals found in basalt has been found to be much higher than that of the primary basalt minerals. For certain radionuclides (strontium, selenium, technetium, neptunium.), the sorptive capacity of primary basalt minerals increases with increasing temperature, while for other elements (cesium and iodine), the sorptive capacity of basalt is inversely proportional to temperature. For some elements, such as radium, the sorptive behavior of basalt. minerals is independent of temperature. For basalt secondary minerals, a temperature-dependent sorptive capacity has been found only in the case of radium, with sorption increasing with increasing temperature. Only a limited number of anoxic sorption experiments have been reported, duplicating oxidation conditions likely to exist in the repository rock (primarily due to speciailized equipment requirements and the difficulty of maintaining very low oxygen fugacities). In such experiments, the sorptive capacity observed for primary and secondary basalt minerals is higher than that seen in oxic systems. In those few experiments reported to date, sorptive capacities of basalt primary minerals appear to be higher under anoxic conditions than those of the secondary minerals.

Erdal et a1. (1979a, 1979b) have studied the sorption and desorption behavior of Climax Stock granite. Results of these experiments are listed in Table $7 . A$ number of general observations have been made in the course of sorption experiments with granites. The sorptive capacity of granite appears to increase as the surface area of the rock increases for all elements tested except technetium, which followed an opposite trend. Variations in $\mathrm{pH}$ produced no effect on the sorption of cesium, strontium, and barium, but some effects are expected for elements such as cerium and europium, which form insoluble hydroxides from pH 8 to 8.5. Desorption experiments, were performed by immersing samples containing sorbed radionuclides in simulated groundwater containing no radionuclides but otherwise 
TABLE 7

SORPTIVE AND DESORPTIVE BEHAVIOR OF SELECTED ISOTOPES ON CLIMAX STOCK GRANITE (Erdal et a1., 1979a, 1979b)

\begin{tabular}{|c|c|c|c|}
\hline \multirow[b]{2}{*}{ Isotope } & \multicolumn{2}{|c|}{$R_{d}, 0 x i c^{a}(m l / g)$} & \multirow{2}{*}{$\frac{\mathrm{R}_{\mathrm{d}} \text {, Anoxic }{ }^{\mathrm{b}}(\mathrm{ml} / \mathrm{g})}{32^{\circ} \mathrm{C} \text {, Sorption }}$} \\
\hline & Sorption & Desorption & \\
\hline$S r^{85}$ & $\begin{array}{l}\text { a. } 16 \pm 1 \\
\text { b. } 38 \pm 5\end{array}$ & $\begin{array}{l}\text { a. } 20 \pm 1 \\
\text { b. } 39 \pm 5\end{array}$ & $19.4-69.8$ \\
\hline $\mathrm{Cs}^{137}$ & $\begin{array}{l}\text { a. } 320 \pm 30 \\
\text { b. } 795 \pm 70\end{array}$ & $\begin{array}{l}\text { a. } 550 \pm 40 \\
\text { b. } 1370\end{array}$ & $752-1780$ \\
\hline $\mathrm{Ba}^{133}$ & $\begin{array}{l}\text { a. } 164 \pm 25 \\
\text { b. } 718 \pm 240\end{array}$ & $\begin{array}{l}\text { a. } 170 \pm 30 \\
\text { b. } 750 \pm 230\end{array}$ & $245-1720$ \\
\hline$C e^{141}$ & $\begin{array}{l}\text { a. } 240 \pm 60 \\
\text { b. } 41 \pm .5\end{array}$ & $\begin{array}{l}\text { a. } 1410 \pm 270 \\
\text { b. } 1050 \pm 190\end{array}$ & $>1400->2600$ \\
\hline $\mathrm{Eu}^{152}$ & $\begin{array}{l}\text { a. } 550 \pm 150 \\
\text { b. } 71+12\end{array}$ & $\begin{array}{l}\text { a. } 1500 \pm 250 \\
\text { b. } 1160 \pm 140\end{array}$ & $>1100->5300$ \\
\hline$A m$ & $\begin{array}{l}\text { a. } 3800 \pm 1100 \\
\text { b. } 10,000-37,000\end{array}$ & $\begin{array}{l}\text { a. } 1000 \pm 410 \\
\text { b. } 1200 \pm 740\end{array}$ & $N R^{C}$ \\
\hline $\mathrm{Pu}$ & $\begin{array}{l}\text { a. } 1500 \pm 330 \\
\text { b. } 3800-15,000\end{array}$ & $\begin{array}{l}\text { a. NR } \\
\text { b. NR }\end{array}$ & NR \\
\hline Tc & $\begin{array}{l}\text { a. } \sim 30 \\
\text { b. } \sim 10\end{array}$ & $\begin{array}{l}\text { a. } \sim 100 \\
\text { b. } \sim 100\end{array}$ & NR \\
\hline U & $\begin{array}{l}\text { a. } 4.4 \pm 1 \\
\text { b. } N R\end{array}$ & $\begin{array}{l}\text { a. } 15 \pm 2 \\
\text { b. } N R\end{array}$ & NR \\
\hline
\end{tabular}

$a_{a}=22^{\circ} \mathrm{C}, b=70^{\circ} \mathrm{C}$, for 3 - to 8-week equilibrations in simulated C1 imax Stock groundwater

$b_{3 \text {-week sorption times in simulated } C l i m a x}$ Stock groundwater, <0.2. $\mathrm{ppm} \mathrm{O}_{2}$

$\mathrm{C}_{\mathrm{NR}}=$ not reported 
identical to that used in the sorption experiments. In general, desorption $R_{d}$ (distribution ratio = concentration of radionuclide in solid per gram/concentration of radionuclide in solution per milliliter) values are higher than those found in the sorption experiments (with the exceptions of europium and americium). Desorption $R_{d}$ values much larger than those for sorption suggest that little of the sorbed radionuclide was released by the rock. Observed $R_{d}$ values for the sorption of strontium, cesium, barium, americium, and plutonium increased with increasing temperature but decreased for cerium, europium, and technetium. A reduced availability of oxygen in the system increased the sorptive capacity of granite for all elements studied. This effect may reflect differences in the oxidation state of the rock surface in soiutions with a. low dissolved-oxygen content. It may also indicate precipitation of a solid phase containing the cation, reflecting a reduced stability of the element in solution. Detailed descriptions of the mechanisms underlying such changes have not been reported.

The sorptive behavior of salt and other minerals indigenous to salt formations is reported for several elements in Table 8 . While halite, dolomite, and polyhalite exhibit relatively little sorptive capacity, clay, anhydrite, and the Hainesville samples (mostly quartz, with some clay) have respectable $R_{d}$ values. For the Hainesville samples, $R_{d}$ values are generally higher for materials from the aquifer zones than those from the aquitard (a confining bed of rock which retards but does not prevent the flow of water to or from an adjacent aquifer). Oxygen fugacity apparently has very little effect on the sorption of cesium, strontium, barium, europium, and cerium by clay, anhydrite, and the Hainesville samples. These materials also exhibit surprisingly high sorptive capacities for cesium and uranium.

Data from sorption experiments with Eleana argillite are presented in Table 9. Argillite shows excellent sorption characteristics for all radionuclides studied except technetium and uranium. Eliminating oxygen from the experiment appears to increase the sorption of cerium, europium, and uranium by the argillite and to decrease the sorption of strontium, cesium, and barium. The sorptive capacity of the argillite increases with increasing temperature for

DOE/ET/41900-13

(ESG-DOE-13364) 
TABLE 8

SORPTIVE BEHAVIOR OF MINERALS IN THE DELAWARE BASIN AND ADJACENT TO THE HAINESVILLE SALT DOME (Powers et al., 1978; Erdal et al., 1979b)

\begin{tabular}{|c|c|c|c|c|c|c|c|c|}
\hline & \multirow[b]{2}{*}{$\begin{array}{l}\text { Radio- } \\
\text { nuclide }\end{array}$} & \multicolumn{6}{|c|}{ Sorption Ratio, $R_{d}(\mathrm{~m} / / \mathrm{g})$} & \multirow{2}{*}{$\begin{array}{l}\text { "Aquitard" } \\
\text { Solids - } \\
\text { Hainesville }\end{array}$} \\
\hline & & $\begin{array}{c}\text { Magenta } \\
\text { Dolomite, } \\
\text { WIPPa }\end{array}$ & $\begin{array}{l}\text { WIPP } \\
\text { Halite }\end{array}$ & $\begin{array}{l}\text { WIPF } \\
\text { Clayc. }\end{array}$ & $\begin{array}{c}\text { WIPP } \\
\text { Polyhalite }\end{array}$ & $\begin{array}{c}\text { Cowden } \\
\text { Anhydrite, } \\
\text { WIPPe }\end{array}$ & $\begin{array}{l}\text { "Aquifer" } \\
\text { Solids - } f \\
\text { Hainesville }\end{array}$ & \\
\hline \multirow{11}{*}{ 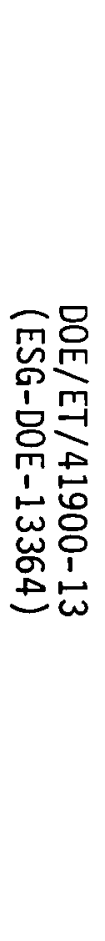 } & $\mathrm{Cs}$ & $<1$ & $N R^{g}$ & $3-6$ & $<1$ & NR & $\begin{array}{l}\text { a. } 3,720 \\
\text { b. } 3,550\end{array}$ & $\begin{array}{l}\text { a. } 5,280 \\
\text { b. } 4,230\end{array}$ \\
\hline & $S r$ & 1 & NR & $<1$ & $19-22$ & $N R$ & $\begin{array}{l}\text { a. } 7.70 \\
\text { b. } 7.64\end{array}$ & $\begin{array}{l}\text { a. } 10.10 \\
\text { b. } 9.80\end{array}$ \\
\hline & $\mathrm{Ba}$ & NR & NR & NR & NR & NR & $\begin{array}{l}\text { a. } 23.5 \\
\text { b. } 25.0\end{array}$ & $\begin{array}{l}\text { a. } 16.8 \\
\text { b. } 15.7\end{array}$ \\
\hline & $\mathrm{I}, \mathrm{Tc}$ & $<1$ & NR & $<1$ & $<1^{h}$ & NR & NR & NR \\
\hline & $\begin{array}{c}E u, G d \\
\cdot .\end{array}$ & $>5,000$ & NR & $>10,000$ & $430-700^{i}$ & $>1,000$ & $\begin{array}{l}\text { a. } 1,780^{i} \\
\text { b. } 1,710\end{array}$ & $\begin{array}{l}\text { i. } 338^{i} \\
\text { b. } 352\end{array}$ \\
\hline & $\mathrm{Ru}$ & $500-600$ & NR & $>1,000$ & NR & NR & NR & NR \\
\hline & $\mathrm{Pu}$ & 5,400 & $\begin{array}{c}17^{j} \\
(10,000)\end{array}$ & 310 & NR & 290 & NR & NR \\
\hline & $A m$ & 3,100 & $\begin{array}{c}306^{j} \\
(180,000)\end{array}$ & 72,000 & NR & 6,700 & $\begin{array}{l}\text { a. } 2,290 \\
\text { b. } 2,680\end{array}$ & $\begin{array}{l}\text { a. } 326 \\
\text { b. } 319\end{array}$ \\
\hline & $\mathrm{Cm}$ & 1,300 & $\begin{array}{c}354^{j} \\
(210,000)\end{array}$ & 2,700 & NR & 4,200 & NF: & NRR \\
\hline & $u^{6+}$ & NR & NR & NR & NR & NR & $\begin{array}{l}\text { a. } 9,200 \\
\text { b. } 5,730\end{array}$ & $\begin{array}{l}\text { a. } 557 \\
\text { b. } 237\end{array}$ \\
\hline & $\mathrm{Ce}$ & NR & NR & NR & $50-55$ & $>1,000$ & $\begin{array}{l}\text { a. } 988 \\
\text { b. } 973\end{array}$ & $\begin{array}{l}\text { a. } 316 \\
\text { b. } 329\end{array}$ \\
\hline
\end{tabular}

$a_{A 11}$ WIPP data for radionuclides in WIPP Brine $B$, pH of $6.5-7.9 \quad g_{N R}=$ not reported

$\begin{array}{ll}\mathrm{b}_{627} \mathrm{~m} \text { Horizon, Corehole } 9 & h_{\text {Tc only }}\end{array}$

$831 \mathrm{~m}$ Horizon, Corehole 8

702 m Horizon, Corehole 9

f 781 m Horizon, Corehole 8

$\mathrm{f}_{\mathrm{a}}=$ oxic water, $\mathrm{b}=$ anoxic water $\left(<0.2 \mathrm{ppm} \mathrm{O}_{2}\right)$, brine values

${ }^{j}$ Values in parentheses calcu-

lated for $\mathrm{H}_{2} \mathrm{O}$ insoluble

fraction onfy; small values

for total sample 
TABLE 9

SORPTION OF SELECTED RADIONUCLIDES BY ARGILLITE FROM THE ELEANA FORMATION, NEVADA TEST SITE (Dosch and Lynch, 1979; Erdal et al., 1979b; 1979c)

\begin{tabular}{|c|c|c|c|c|c|c|}
\hline \multirow{2}{*}{$\begin{array}{l}\text { Radio- } \\
\text { nuclide }\end{array}$} & \multirow{2}{*}{$\begin{array}{c}\text { Time } \\
\text { (days) }\end{array}$} & \multirow{2}{*}{$\begin{array}{l}\text { Temp. } \\
\text { ( } \cdot \mathrm{C})\end{array}$} & \multirow[b]{2}{*}{ Final $\mathrm{pH}$} & \multicolumn{3}{|c|}{$R_{d}(m l / g)$} \\
\hline & & & & Oxic & & noxic ${ }^{a}$ \\
\hline Sr. & $\begin{array}{l}56 \\
56 \\
21\end{array}$ & $\begin{array}{l}22 \\
70 \\
32\end{array}$ & $\begin{array}{l}8.69-9.06 \\
8.48-8.52 \\
8.55-8.68\end{array}$ & $\begin{array}{c}138-202 \\
265-622 \\
\text { NR }\end{array}$ & 31. & $\begin{array}{l}N^{b} \\
\text { NR } \\
9-32.1\end{array}$ \\
\hline $\mathrm{Cs}$ & $\begin{array}{l}56 \\
56 \\
21\end{array}$ & $\begin{array}{l}22 \\
70 \\
32\end{array}$ & $\begin{array}{l}8.69-9.06 \\
8.48-8.52 \\
8.55-8.68\end{array}$ & $\begin{array}{c}1,580-2,540 \\
1,200-2,810 \\
N R\end{array}$ & 1,020 & $\begin{array}{l}\text { NR } \\
\text { NR } \\
0-1,190\end{array}$ \\
\hline $\mathrm{Ba}$ & $\begin{array}{l}56 \\
56 \\
21\end{array}$ & $\begin{array}{l}22 \\
70 \\
32\end{array}$ & $\begin{array}{l}8.69-9.06 \\
8.48-8.52 \\
8.55-8.68\end{array}$ & $\begin{array}{c}4,270-5,290 \\
10,900-33,400 \\
\text { NR }\end{array}$ & 209 & $\begin{array}{l}\text { NR } \\
\text { NR } \\
9-288\end{array}$ \\
\hline $\mathrm{Ce}$ & $\begin{array}{l}56 \\
56 \\
21\end{array}$ & $\begin{array}{l}22 \\
70 \\
32\end{array}$ & $\begin{array}{l}8.69-9.06 \\
8.48-8.52 \\
8.55-8.68\end{array}$ & $\begin{array}{c}31,200-47,400 \\
8,660-26,000 \\
\text { NR }\end{array}$ & $>110,000$ & $\begin{array}{l}\text { NR } \\
\text { NR } \\
->128,000\end{array}$ \\
\hline $\mathrm{Eu}$ & $\begin{array}{l}56 \\
56 \\
21\end{array}$ & $\begin{array}{l}22 \\
70 \\
32\end{array}$ & $\begin{array}{l}8.69-9.06 \\
8.48-8.52 \\
8.55-8.68\end{array}$ & $\begin{array}{c}26,800-40,300 \\
9,360-24,500 \\
\text { NR }\end{array}$ & $>400,000$ & $\begin{array}{l}\text { NR } \\
\text { NR } \\
->440,000\end{array}$ \\
\hline $\mathrm{Am}^{\mathrm{C}}$ & $\begin{array}{l}55 \\
56\end{array}$ & $\begin{array}{l}22 \\
70\end{array}$ & $\begin{array}{l}8.21-8.68 \\
7.73-8.02\end{array}$ & $\begin{array}{r}75,000-300,000 \\
6,500-450,000\end{array}$ & & $\begin{array}{l}\text { NR } \\
\text { NR }\end{array}$ \\
\hline $\mathrm{Pu}{ }^{\mathrm{C}}$ & $\begin{array}{l}57 \\
57\end{array}$ & $\begin{array}{l}22 \\
70\end{array}$ & $\begin{array}{l}8.54-8.65 \\
8.32-8.46\end{array}$ & $\begin{array}{l}4,200-37,000 \\
2,100-75,000\end{array}$ & & $\begin{array}{l}\text { NR } \\
\text { NR }\end{array}$ \\
\hline Tc & $\begin{array}{l}59 \\
60\end{array}$ & $\begin{array}{l}22 \\
70\end{array}$ & $\begin{array}{l}8.20-8.47 \\
8.46-8.65\end{array}$ & $\begin{array}{l}16.2=225 \\
1.06-12.4\end{array}$ & & $\begin{array}{l}\text { NR } \\
\text { NR }\end{array}$ \\
\hline U & $\begin{array}{l}21 \\
21\end{array}$ & $\begin{array}{l}22 \\
32\end{array}$ & $\begin{array}{l}8.58-8.69 \\
8.55-8.68\end{array}$ & $3.1-107$ & 7.26 & $\begin{array}{l}\text { NR } \\
-8.91\end{array}$ \\
\hline $\mathrm{Cm}$ & 56 & 22 & $8.1-8.2$ & $240-\infty$ & & NR \\
\hline
\end{tabular}

$\mathrm{a}_{0.2 \mathrm{ppm}} \mathrm{O}_{2}$

$\mathrm{b}_{\mathrm{NR}}=$ not reported

${ }^{C}$ First value for unfiltered solution, second for solutions filtered to remove suspended particulates 
strontium, barium, and plutonium and decreases for cerium, europium, americium, and technetium. The absence of dissolved $\mathrm{CO}_{2}$ in the anoxic experiments may (at least partially) explain these changes (Erdal et al., 1979b).

Sorption data for various tuffs are presented in Table 10. The data indicate that sorption of various elements is highly dependent on the mineralogy of the specific tuff in question. It appears that whichever radionuclide is not sorbed well by one type of tuff will be effectively sorbed by another type. Therefore, an advantage of the Nevada Test Site tuffs is the variety of mineralogies present in them. This variable mineralogy provides a natural multiple barrier to the migration of leached radionuclides. 
TABLE. 10

SORPTION RATIOS FOR VARIOUS NEVADA TEST SITE TUFFS $(\mathrm{m} 1 / \mathrm{g})$

(Tyler, 1979)

\begin{tabular}{cccc}
\hline $\begin{array}{l}\text { Radio- } \\
\text { nuclide }\end{array}$ & $\begin{array}{c}\text { Densely Welded } \\
\text { (Glass, Moderately } \\
\text { Zeolitized) }\end{array}$ & $\begin{array}{c}\text { Partially Welded } \\
\text { (Devitrified, Low } \\
\text { in Zeolite) }\end{array}$ & $\begin{array}{c}\text { Partially Welded } \\
\text { (No. Glass, High } \\
\text { in Zeolite) }\end{array}$ \\
\hline Sr & 10,000 & 50 & 300 \\
Cs & 20,000 & 200 & 600 \\
$\mathrm{Ba}$ & 4,000 & 400 & 700 \\
$\mathrm{Eu}$ & 30 & 200 & 6,000 \\
$\mathrm{Pu}$ & 200 & 2,000 & 10,000 \\
$\mathrm{Am}$ & 200 & 1,000 & 7,000 \\
\hline
\end{tabular}

Cation Exchange Parameters

\begin{tabular}{llll}
\hline $\begin{array}{l}\text { Capacity } \\
(M E Q / 100 \mathrm{~g})\end{array}$ & 75 & 2 & 17 \\
$\begin{array}{l}\text { Surface } \\
\text { Area } \\
(\mathrm{m} 2 / \mathrm{g}) *\end{array}$ & 7.5 & 3.3 & 10 \\
\hline
\end{tabular}

* Measurement method not reported. 


\section{MIGRATION}

The host rock and its surrounding geology will be the final barrier impeding transport of radionuclides to man's ecosphere. In the previous section, the sorptive properties of various host-rock materials were discussed. In this section, the variables and conditions accounted for in models of and experiments on radionuclide migration through geologic media are examined.

A list of factors involved in the estimation of radionuclide migration is given in Table 11. Site-specific information on each factor is gradually becoming available. As more reliable data are collected, more realistic migration models can be devised and experiments that more accurately reflect actual conditions in the geologic system can be designed and performed, with the aim of answering pertinent questions.

It has been shown (Crowe and Wolfsberg, 1980) that for most cases, the simple relation between the distribution coefficient $R_{d}$ and the relative migration rates of radionuclides with respect to groundwater velocity is insufficient to permit accurate modeling of the retardation of radionuclides. This indicates the need to isolate and study the many mechanisms causing the retardation (e.g., rates of sorption, desorption, precipitation, dispersion, etc., which vary in response to changes in the factors listed in Table 11). This, in turn, could lead to an understanding of the relationship between behavior in a dynamic laboratory experiment (and, ultimately, behavior in the field) and the many available batch $R_{d}$ data. $R_{d}$ values determined in dynamic experiments (few of which exist) can better approximate field conditions than those determined under static conditions.

The Waste Rock Interaction Technology (WRIT, formerly the Waste Isolation Safety Assessment Program, or WISAP) program has been spearheading the generation of pertinent data and the development of geochemical models for simulating radionuclide migration. Much of this work has been discussed in the proceedings of WISAP contractor-information meetings (Serne, 1978; Relyea, 1979) and other summary documents (Steindler et a1., 1980; Deutsch, 1980). Investigators in 
TABLE 11

FACTORS INVOLVED IN RADIONUCLIDE MIGRATION ESTIMATES

\begin{tabular}{|c|c|c|c|}
\hline Waste Form & Groundwater & Host Rock & Other Geology \\
\hline $\begin{array}{l}\text { Durability } \\
\text { Surface Area } \\
\text { Age } \\
\text { Radionuclide } \\
\text { half-lives } \\
\text { Engineered } \\
\text { barriers }\end{array}$ & $\begin{array}{l}\text { Flow Rate } \\
\text { Composition } \\
\text { pH } \\
\text { Composition } \\
\text { Eh }\end{array}$ & $\begin{array}{l}\text { Sorptive capacity } \\
\text { Bulk density } \\
\text { Porosity } \\
\text { Permeability } \\
\text { Reconcentration } \\
\text { phenomena (e.g., } \\
\text { orebody forma- } \\
\text { tion) }\end{array}$ & $\begin{array}{l}\text { Fissures } \\
\text { Seismicity } \\
\text { Composition } \\
\text { Length of flow path } \\
\text { (time and distance) } \\
\text { Hydrostatic pressure } \\
\text { Lithostatic pressure } \\
\text { Geothermal gradient } \\
\text { (local temperature) } \\
\text { Volcanism } \\
\text { (changes flow path) }\end{array}$ \\
\hline
\end{tabular}

DOE/ET/41900-13

(ESG-DOE-13364) 
Switzerland and Germany are also developing their own models and data bases (Hadermann, 1980; Schwarzer, 1979).

Several other factors (not listed in Table 11) must also be considered in the estimation of radionuclide release to the biosphere. Most models are onedimensional and do not allow for vertical and horizuntal dispersion of the groundwater flow. It is more conservative to assume straight-line flow, as the dispersion is certain to retard migration and slow the eventual radionuclide release. (It is unlikely to stop the release or reduce the overall amount of long-lived radionuclides that reach the biosphere, however.) Three-dimensional finite-element models are now being developed to assist in evaluating the effects of dispersion (Gupta et al., 1979).

The release of radionuclides may occur by either diffusion or particulate migration. There are obvious differences between these mechanisms, and each is affected differently by such factors as groundwater flow, rock permeability and sorptive capacity, etc. Most models assume that migration involves only the movement of trace quantities of radionuclides dissolved in the groundwater.

Another option being considered is partitioning certain species from the waste in the hopes of minimizing long-term release. Cloninger (1980) has discussed this subject and concludes that only under certain circumstances might there be an advantage to partitioning elements such as plutonium, uranium, carbon, technetium, iodine, americium, and neptunium. It was found that the precursors of ${ }^{226} \mathrm{Ra}$ (uranium and plutonium) may be the most important species to isolate.

Perhaps the most complete discussion of radionuclide release scenarios was given by cole and Bond (1980). This is an extensive outline of four hypothetical situations involving detailed site characterization, release scenarios, hydrologic, transport, and dose modeling, and modeling of engineered barriers and leach rate. Cole and Bond demonstrated that numerical modeling is a useful 
approach for assessing the safety of geologic repositories and concluded that the geologic media separating waste in a repository from natural release points reduce the effects of a release. As far as the model is concerned, the authors were satisfied with the treatment of far-field effects, transport mechanisms, and dose methodology but called for improved models of near-field factors (e.g., engineered barriers, repository design, etc.).

Prickett, Voorhees, and Herzog (1980) compared one-, two-, and threedimensional models of hydrologic transport of radionuclides. They cautioned against using one- and two-dimensional models except in well-known, well-defined situations. Examples of assumptions that might result in misleading conclusions are that diffusion and dispersion are negligible in any direction or that the repository is a point source.

In summary, the study of radionuclide migration in geologic media is in its infancy. The results of many studies now in progress will provide information concerning the interrelationships of the numerous factors involved in evaluating radionuclide transport. Models that can be used to confirm past experimental results and to forecast the results of proposed experiments are being developed simultaneously. The present state of the art indicates that the geohydrologic system will be highly effective in preventing premature release of radionuclides into the biosphere. 


\section{VI: SUMMARY AND CONCLUSIONS}

The relative durabilities of prototype ceramic nuclear waste forms and borosilicate glass have been reviewed insofar as data are available. A wide range of leaching data is available for borosilicate glass, while less is available for the prototype ceramic waste forms. In this respect, the relative availability of data is roughly proportional to the age of the given waste-form concept. In all cases, hydrothermal leaching data, especially in realistic experiments that include repository rock, are either very limited or nonexistent.

Based upon the amount of data available, some tentative conclusions may be drawn. In order of resistance to attack by typical repository or other leaching solutions, coated ceramic (Rusin et al., 1980) appears to be the most resistant, followed by supercalcine ceramic, SYNROC, and, finally, glass. For specimens containing simulated commercial fuel wastes (the most extensively tested versions), supercalcine ceramic exhibits better performance than SYNROC in. some respects and matches it in others, while possessing a 3 - to 6 -fold greater waste loading.

Deionized water and saline brines appear to be the solutions harshest on the waste forms examined in this report. Glass outperforms supercalcine ceramic in a hot $\mathrm{NaCl}$ brine, but the rankings remain the same otherwise. Based on the limited amount of data presently available, the relative stabilities of the waste forms appear to be the same as discussed in the preceding paragraph when the waste form is in contact with both water and repository rock. The important feature of reactions that include repository rock is the precipitation of new, stable mineral phases that trap many of the leached radionuclides, as mentioned earlier.

Much work remains to be accomplished to adequately address ceramic waste-form stability in a repository system. Studies of waste-form reactions with some systems, such as tuff and granite, have not been reported. In the others, the data are limited. Rigorous examination and quantification of the variables that can

$\mathrm{DOE} / \mathrm{ET} / 41900-13$

(ESG-D0E-13364) 
influence waste-form reactions with candidate repository geologies are required. Such information should allow waste-form modifications or engineered barriers to be devised.so that the consequences to man of groundwater intrusion into the repository and the waste canisters are minimized. 


\section{BIBLIOGRAPHY}

Bischoff J. L., and F. W. Dickson (1976), "Seawater Basalt Interactions at $200^{\circ} \mathrm{C}, 500$ Bars--Implication for Origin of Sea-Floor Heavy Metal Deposits and Regulation of Seawater Chemistry," Earth Planet Sciences Letters, 25, 385-397

Bradley, D. J. (1980), "Basic Research for Evaluation of Nuclear Waste Form Performance," Nucl. Technol., 51, 111-122

Bradley, D. J., C. 0. Harvey, and R. P. Turcotte (1979), "Leaching of Actinides and Technetium from Simulated High-Level Waste GTass," PNL-3152, Pacific Northwest Laboratory, Richland, Washington

Brawer, S. A., G. Thompson, and W. B. White (1975), "Leaching Behavior of Glass Encapsulants for Radioactive Waste," unnumbered report to the Atlantic Richfield Hanford Company, The Pennsylvania State University, University Park, Pennsylvania

Cloninger, M. 0. (1980), "Incentives for Partitioning, Revisited," PNL-SA-8491, Pacific Northwest Laboratories, Richland, Washington

Cole, C. R., and F. W. Bond (1980), "Summary of Four Release Consequence Analyses for Hypothetical Nuclear Waste Repositories in Salt and Granite," PNL-3548, Pacific Northwest Laboratories, Richland, Washington

Coons, W. E. (1981), "Physicochemical Conditions in a Nuclear Waste Repository Situated in Columbia River Basalt," Scientific Basis for Nuclear Waste Management, Vol. 3, J. G. Moore, Ed., (in press; presented at the Materials Research Society Annual Meeting, November 16-21, 1980, Boston, Massachusetts)

Coons, W. E., E. S. Patera, and M. I. Wood (1980), "Waste Form/Basalt/Barrier Interactions Under Hydrothermal Conditions," Basalt Waste Isolation Project Annual Report, Fiscal Year 1980, RH0-BWI-80-100, Rockwell Hanford Operations, Richland, Washington, IV. 16 - IV.22

Crowe, B. M., and K. Wolfsberg (1980), "Research and Development Related to the Nevada Nuclear Waste Storage Investigations, January 1 - March 31, 1980," LASL-8419-PR, Los Alamos Scientific Laboratory, Los Alamos, New Mexico

Deutsch, W. J. (1980), "Geochemical Modeling of the Nuclear Waste Repository System - A Status Report," PNL-3518, Pacific Northwest Laboratories, Richland, Washington

Dosch, R. G., and A. W. Lynch (1979), "Interactions of Radionuclides with Argillite from the Eleana Formation of the Nevada Test Site," SAND-78-0893, Sandia Laboratories, Albuquerque, New Mexico

DOE/ET/41900-13

(ESG-D0E-13364) 
Eaton, R. R., et al. (1980), "Calculated Hydrogeologic Pressures and Temperatures Resulting from Radioactive Waste in the Eleana Argillite," Scientific Basis. for Nuclear Waste Management, Vol. 2, C. J. M. Northrup, Ed., Plenum, New York, 833-840

Erda1, B. R., et a1. (1979a); "Sorption-Desorption Studies on Granite. I. Initial Studies of Strontium, Technetium, Cesium, Barium, Cerium, Europium, Uranium, Plutonium, and Americium," LA-7456-MS, Los Alamos Scientific Laboratory, Los Alamos, New Mexico

Erdal, B. R., et al. (1979b), "Laboratory Studies of Radionuclide Distribution Between Selected Groundwaters and Geologic Media;" in Relyea, J. F., "Waste Isolation Safety Assessment Program, Task 4: Third Contractor Information Meeting, Vol. 1," PNL-SA-8571, 435-525, Pacific Northwest Laboratories, Richland, Washington

Erda 1, B. R., et a1. (1979c), "Sorption-Desorption Studies on Argillite. I. Initial Studies of Strontium, Technetium, Cesium, Barium, Cerium and Europium," LA-7455-MS, LoS Alamos Scientific Laboratory, Los Alamos, New Mexico

Freeborn, W. P., et a1. (1980), "Shale Rocks as Nuclear Waste Repositories: Hydrothermal Reactions with Glass, Ceramic and. Spent Fuel Waste Forms," Scientific Basis for Nuclear Waste Management, Vol. 2, C. J. M. Northrup, Ed., Plenum, New York, 499-506

Gupta, S. M., C. R. Cole, and F.: W. Bond (1979), "Finite-Element Three-Dimensional Groundwater (FE3DGW) Flow Mode1 - Formulation, Program Listings and User's Manual," PNL-2939, Pacific-Northwest Laboratories, Richland; Washington

Hadermann, J. (1980), "Radionuclide Transport Through Heterogeneous Media," Nucl. Technol., 47, 312-323

Harker; A., et al. (1980a), "Review of Status of High-Al Tailored Ceramic Nuclear Wasteform Development," DIT-80-1, Rockwell International Science Center, Thousand Oaks, California

Harker, A. B., et al. (1980b), "The Effect of Interfacial Material on Tailored Ceramic Nuclear Waste Form Dissolution," presented at Conference on Surfaces and Interfaces in Ceramic and Ceramic-Metal Systems, July 28 - August 1 , 1980, Berkeley, California

Johnston, R. G.; and R. A. Palmer (1981), "Characteristics of Candidate Geologies for Nuclear Waste Isolation: A Review," DOE/ET/41900-6, Rockwell Hanford Operations, Richland, Washington

DOE/ET/41900-13

(ESG-DOE-13364) 
Kaplan, M. F. (1980), "Characterization of Weathered Glass by Analyzing Ancient Artifacts," Scientific Basis for Nuclear Waste Management; Vol. 2,

C. J. M. Northrup,. Ed., Plenum, New York, 85-92

Kenna, B. T., K. D. Murphy, and H. S. Levine (1979), "Long-Term Elevated Temperature Leaching of Solid Waste Forms," Scientific Basis for Nuclear Waste Management, Vol. 1, G. J. McCarthy, Ed., Plenum, New York, 157-160

Komarneni, S., et al. (1980a), "Hydrothermal Interaction of a Ceramic Waste Form with Basalt," presented at Workshop on Alternate Nuclear Waste Forms and Interactions in Geologic Media, May 13-15, 1980, Gatlinburg, Tennessee

Komarneni, S., et al. (1980b), "Hydrothermal Interactions of Cesium and Strontium Phases from Spent Unreprocessed Fuel with Basalt Phases and Basalts," RH0-BWI-C-70, Pennsylvania State University, University Park, Pennsylvania

Langmuir, D. (1978), "Uranium Solution-Mineral Equilibria at Low Temperatures with Appiications to Sedimentary Ore Deposits," Geochimica et Cosmochimica Acta, 42, 547-569

McCarthy, G. J. (1977), "High Level Waste Ceramics: Material Considerations, Process Simulation, and Product Characterization," Nucl. Technol., 32, 91-105

McCarthy, G. J., et al. (1979a), "Hydrothermal Reactivity of Simulated Nuclear Waste Forms and Water-Catalyzed Waste-Rock Interactions, "Scientific Basis for Nuclear Waste Management, Vol. 1, G. J. McCarthy, Ed., , Plenum, New York, 329-340

McCarthy, G. J., et al. (1980), "Hydrothermal Stability of Simulated Waste Glass," Advances in Chemistry Series, No. 186. Sol id State Chemistry: A Contemporary Overview, S. L. Holt, J. B. Milstein, and M. Robbins, Eds., American Chemical Society

McCarthy, G. J., et al. (1979b), "Hydrothermal Stability of Spent Fuel and HighLevel Waste Ceramics in the Geologic Repository Environment," Ceramics in Nuclear Waste Management, T. D. Chikalla and J. E. Mendel, Eds., CONF-790420, Technical Information Center, Springfield, Virginia, 274-276

McCarthy, G. J., et a1. (1978), "Interactions Between Nuclear Waste and Surrounding Rock," Nature, 273, 216-217

McElroy, J. L. (1977), "Quarterly Progress Report, Research and Development Activities, Waste Fixation Program," PNL-2625, Pacific Northwest Laboratories, Richland, Washington

Mendel, J. E., et ai. (1977), Annual Report on the Characteristics of High-Level Waste Glasses, BNWL-2252, Battelle Pacific Northwest Laboratories, Richland, Washington 
Nesbit, H. W., et al. (1980), "On. the Thermodynamic and Kinetic Stability of Perovskite in Natural Waters," presented at Workshop on Alternate Nuclear Waste Forms and Interactions in Geologic Media, May 13-15, 1980, Gatl inburg, Tennessee

Newkirk, H. W. , et a' (1980), "Status of SYNROC Technology for Immobilizing U.S. Defense Wastes,". Paper 15-N-80P, presented at American Ceramic Society, Nuclear Division Fall Meeting, October 27, 1980, San Francisco, California

Powers, D. W. , et al.., Editors (1978), "Geological Characterization Report: Waste Isolation, Pilot Plant (WIPP) Site, Southeastern New Mexico, Volumes 1 and 2," SAND-78-1596, Sandia Laboratories, Albuquerque, New. Mexico

Prickett, T. A., M. L. Voorhees, and B. L. Herzog (1980), "Comparison of One-, Two-, and Three-Dimensional Models for Mass Transport of Radio-Nuclides," UCRL-15210, report to Lawrence Livermore Laboratories from Camp, Dresser and McKee, Water Resources Division, Champaign, I11 inois

Relyea, J. F., Ed. (1979), "Waste Isolation Safety Assessment Program, Task 4: Third Contractor Information Meeting," PNL-SA-8571, Pacific Northwest Laboratories, Richland, Washington

Rich, R. A., H. D. Holland, and U. Peterson (1977), Hydothermal Uranium Deposits, Elsevier, Amsterdam; The Netherlands

Ringwood, A. E. (1978), Safe Disposal of High Level Nuclear Reactor Wastes: A New Strategy, Australian National University Press, Canberra, Australia

Ringwood, A. E., et al. (1979a), "Immobilization of High Level Nuclear Reactor Wastes in SYNROC," Nature, 278, 219-223

Ringwood, A. E., et àl. (1979b), "The SYNROC Process: A Geochemical Approach to Nuclear Isolation," Geochemical Journal, 13, 141-165

Rockweil Hanford Operations (1980), "Long-Term High-Level Défense Waste Technology, Progress Report, January - March 1980," RHO-LD-80-101B, Rockwe 11 Hanford Operations, Richland, Washington

Ross, W. A., and J. E. Mendel (1979), "Annual Report on the Development of Solidified Forms of High-Level Wastes: 1978," PNL-3060, Pacific Northwest Laboratories, Richland, Washington

Ross, W. A., R. P. Turcotte, J. E. Mendel, and J. M. Rusin (1979), A Comparison of Glass and Crystalline Waste Materials, PNL-SA-7530, Pacific Northwest Laboratories, Richland, Washington

Rusin, J. M. (1980), "A Review of High-Level Waste Form Properties," PNL-3035, Pacific Northwest Laboratories, Richland, Washington

DOE/ET/41900-13

(ESG-DOE-13364) 
Rusin, J. M., M. F. Browning, and G. J. McCarthy (1979), "Development of Multibarrier Waste Forms," Scientific Basis for Nuclear Waste Management, Vol. 1, G. J. McCarthy, Ed., Plenum, New York, 169-180

Rusin, J. M., et al. (1980), "Chemically Vapor Deposited Coatings for Multibarrier Containment of Nuclear Wastes," presented at The Workshop on Alternate Nuclear Waste Forms and Interactions in Geologic Media, May 13-15, Gatlinburg, Tennessee

Scheetz, B. E., S. Komarneni, and D. K. Smith (1979), "Status of the Static, Closed System, Hydrothermal Alteration Experiments of Simulated Nuclear Waste Forms," Basalt Waste Isolation Project - Annual Report, 1979, RH0-BWI-79-100, Rockwe11 Hanford Operations, Richland, Washington, IV. 12-IV.14

Scheetz, B. E., et al. (1980), "Hydrothermal Interaction of Simulated Nuclear Waste Glass in the Presence of Basalts," Scientific Basis for Nuclear Waste Management, Vol. 2, C. J. M. Northrup, Ed., Plenum, New York, 207-214

Schwarzer, K. (1979), "Radionuclide Transport in Soil - Description and Application of a Calculational Model," Nucl. Technol., 46, 248-254

Serne, R. J., Ed., (1978), "Proceedings of the Task 4 Waste Isolation Safety Assessment Program Second Contractor Information Meeting," PNL-SA-7352, Pacific Northwest Laboratories, Richland, Washington

Smith, M. J., et al. (1980), "Engineered Barrier Development for a Nuclear Waste Repository in Basalt: An Integration of Current Knowledge," RHO-BWI-ST-7, Rockwell Hanford Operations, Richland, Washington

Stewart, D. B., and R. W. Potter, II (1979), "Application of Physical Chemistry of Fluids in Rock Salt at Elevated Temperature and Pressure to Repositories for Radioactive Waste," Scientific Basis for Nuclear Waste Management, Vol. 1, G. J. McCarthy, Ed., Plenum, New York, 297-311

Steindler, M. J., et al. (1980), "Fuel Cycle Programs Quarterly Progress Report, July - September 1979," ANL-79-109, Argonne National Laboratory, Argonne, Illinois

Tyler, L. D. (1979), "Evaluation of Tuff as a Waste Isolation Medium," SAND-79-0402C, Sandia Laboratories, Albuquerque, New Mexico

Westsik, J. H., J. W. Shade, and G. L. McVay (1980), "Temperature Dependence for Hydothermal Reactions of Waste Glasses and Ceramics, "Scientific Basis for Nuclear Waste Management, Vol. 2, C. J. M. Northrup, Ed., PTenum, New York, 239-248

Westsik, J. H., and R. P. Turcotte (1978), Hydrothermal Reactions of Nuclear Waste Solids - A Preliminary Report, PNL-2759, Pacific Northwest Laboratories, Richland, Washington 
Westsik, J. H., and R. P. Turcotte (1979), "Hydrothermal Glass Reactions in Sal.t. Brine," Scientific Basis for Nuclear Waste Management, Vol. 1, G. J. McCarthy, Ed., PTenum, New York, 341-344 
Rockwell International

Energy Systems Group

8900 DeSoto Avenue

Canoga Park, California 91304 